
Not for reproduction, distribution or commercial use.

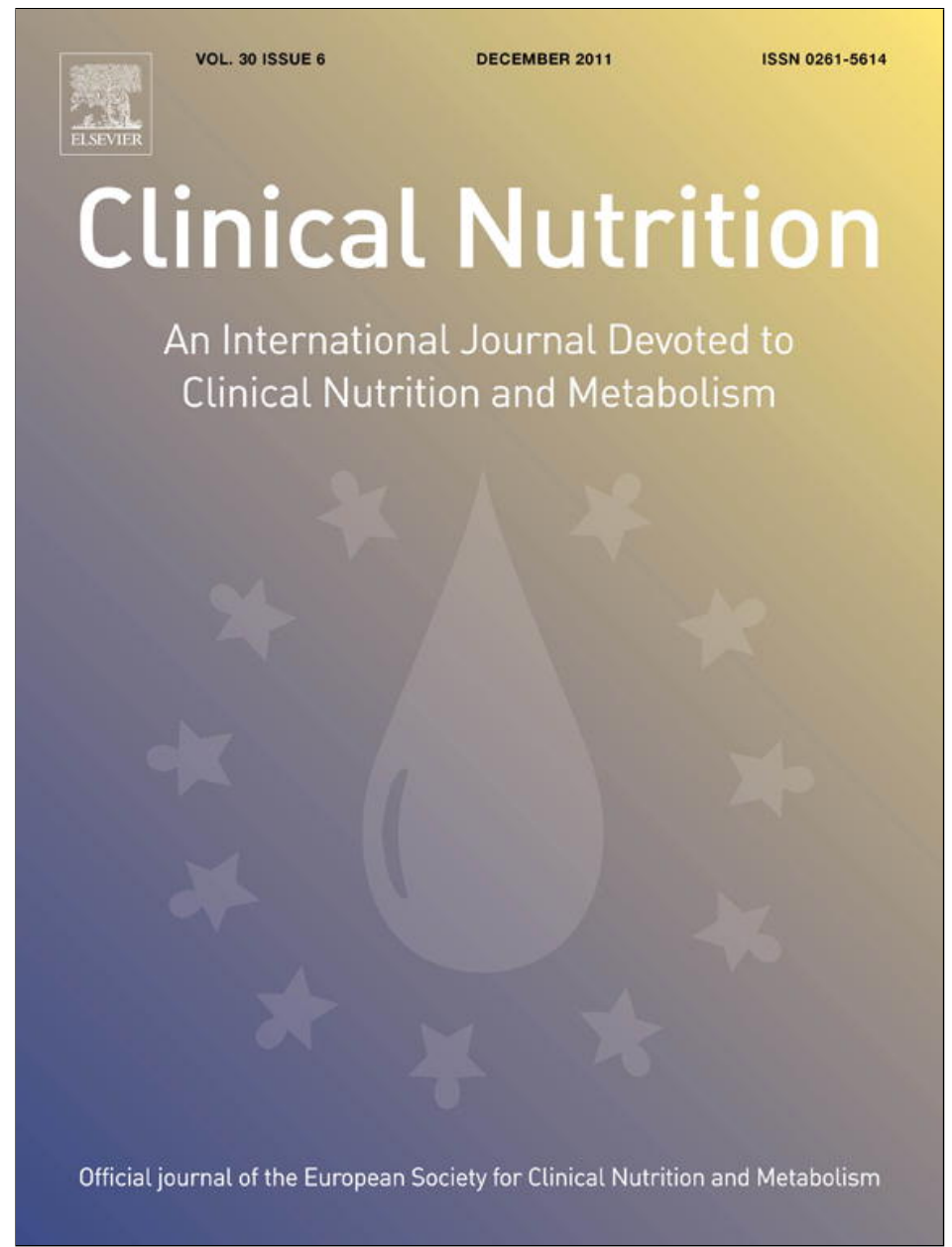

This article appeared in a journal published by Elsevier. The attached copy is furnished to the author for internal non-commercial research and education use, including for instruction at the authors institution and sharing with colleagues.

Other uses, including reproduction and distribution, or selling or licensing copies, or posting to personal, institutional or third party websites are prohibited.

In most cases authors are permitted to post their version of the article (e.g. in Word or Tex form) to their personal website or institutional repository. Authors requiring further information regarding Elsevier's archiving and manuscript policies are encouraged to visit:

http://www.elsevier.com/copyright 
Review

\title{
Micronutrients in pregnancy: Current knowledge and unresolved questions
}

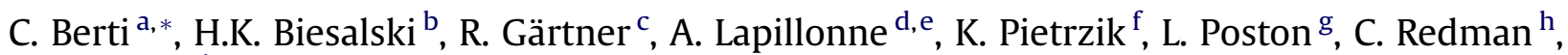 \\ B. Koletzko ${ }^{i}$, I. Cetin ${ }^{\mathrm{a}}$ \\ ${ }^{a}$ Unit of Obstetrics and Gynecology and Center for Fetal Research Giorgio Pardi, University of Milan, Via G. B. Grassi, 74, 20157 Milano, Italy \\ ${ }^{\mathrm{b}}$ Institute of Biological Chemistry and Nutrition, University of Hohenheim, 70599 Stuttgart, Germany \\ ${ }^{\mathrm{c}}$ Medizinische Klinik Innenstadt, University of Munich Medical Centre, München, Germany \\ d Paris Descartes University, APHP Necker Hospital, Paris, France

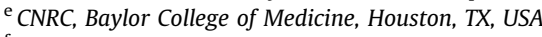 \\ ${ }^{\mathrm{f}}$ Institute of Nutrition and Food Science, University of Bonn, Germany \\ ${ }^{g}$ Division of Women's Health, King's College London and King's Health Partners, London, UK \\ ${ }^{\mathrm{h}}$ Nuffield Department of Obstetrics and Gynaecology, University of Oxford, John Radcliffe Hospital, Oxford, UK \\ ${ }^{i}$ Berthold Koletzko, Dr. von Hauner Children's Hospital, University of Munich Medical Centre, München, Germany
}

\section{A R T I C L E I N F O}

\section{Article history:}

Received 25 March 2011

Accepted 4 August 2011

\section{Keywords:}

Oxidative/inflammation stress

One-carbon metabolism

Pregnancy

Liposoluble vitamins

Minerals

\begin{abstract}
S U M M A R Y
Micronutrient status is increasingly recognized to play an important role in the health and well-being of pregnant women and in the development and long-term health of the offspring. On 26th -28 th February 2009, The Child Health Foundation invited leading experts in this area to a scientific workshop at Obergurgl, Austria to review and critically discuss current knowledge, to identify issues that may need to be addressed in future recommendations, and to highlight priorities and opportunities for future research. This report summarizes updated key conclusions of the workshop with regards to micronutrients' intake and physiological role related to mother, placenta and fetus, as well as relevance for adverse pregnancy and long-term outcomes.
\end{abstract}

(c) 2011 Elsevier Ltd and European Society for Clinical Nutrition and Metabolism. All rights reserved.

\section{Introduction}

A balanced diet with adequate energy intake usually provides an adequate supply of the essential micronutrients. Although a balanced diet is generally accessible for the European population, specific groups have inadequate vitamin and mineral intakes, especially with regards to iron, iodide, folic acid, vitamin $D$ and vitamin $\mathrm{B}_{12}{ }^{1}$ Micronutrient malnutrition represents an important challenge for public health worldwide, particularly in vulnerable population groups such as pregnant women. For example, a study in Hackney, London, showed that $78 \%$ mothers had an inadequate diet, meeting fewer than four of sixteen dietary reference intake values. ${ }^{2}$ Upon follow-up at 9 months post-partum, over half of the un-supplemented, inadequate-diet group remained severely deficient in folate and had low serum ferritin levels. The adequacy of micronutrient intake during pregnancy is related to environmental, cultural and demographic variables, such as maternal age, clothing, geography or socioeconomic status (SES). Studies of plasma biomarkers suggest that SES significantly affects vitamin intakes. In

\footnotetext{
* Corresponding author. Tel.: +39 02 50319804; fax: +39 0250319806. E-mail address: cristiana.berti@gmail.com (C. Berti).
}

the European Prospective Investigation of Cancer Norfolk study, individuals in manual social classes, or those who lived in the most deprived areas had significantly lower levels of plasma ascorbic acid compared to those in non-manual social classes, or who lived in less deprived areas. ${ }^{3}$ Similarly, in a study conducted in the United Kingdom, plasma concentrations of vitamins $\mathrm{C}$ and $\mathrm{B}_{12}$, riboflavin, and beta-carotene were lower in the low-SES group than in the high-SES group. ${ }^{4}$ The French EVA study showed a positive association between SES participants and their selenium and carotenoid status. ${ }^{5}$ Low income pregnant or breastfeeding women are at greater risk of insufficient vitamin and mineral intakes, inducing iron and vitamin A deficiencies. ${ }^{5}$ Indeed, risk for pregnancy related diseases, malformations, preterm birth or low-birthweight (LBW) increases with socioeconomic deprivation and may therefore, at least in part, be related to poor micronutrient status. ${ }^{5}$

\section{The physiological role of micronutrients in pregnancy}

During the childbearing period, many women have inadequate dietary intake of several water soluble vitamins, especially folate. Micronutrient deficiencies or suboptimal/inadequate intakes may be associated with significantly elevated reproductive risks, ranging from infertility to fetal structural defects and long-term 
diseases. $^{6,7}$ Similarly, there is evidence demonstrating a role for micronutrient supplementation reducing the risk of some pregnancy disorders. ${ }^{89}$ Micronutrients may affect pregnancy outcomes through alterations in maternal and fetal metabolism owing to their role/involvement in enzymes activity, signal transduction and transcription pathways, biological functions and oxidative stress, but the biological mechanisms underpinning these associations are not completely understood. ${ }^{10}$

\subsection{Folic acid and vitamin $B_{12}$}

Folate and folic acid serve as the precursors for the coenzyme tetrahydrofolate in single-carbon transfer in the metabolism of amino acids and nucleic acids as well as substrate donors in the remethylation of homocysteine into methionine, catalyzed by methionine synthase and 5,10-methylenetetrahydrofolate reductase (MTHFR). An inadequate dietary folate intake results in a reduction of DNA biosynthesis and thereby of cell division, leading to anemia, leucopenia, thrombocytopenia and other adverse effects. ${ }^{11}$

An overview of one-carbon metabolism is shown in Fig. 1. The predominant folate transport and storage form within the body is 5-methyltetrahydrofolate (5-MTHF). Synthetic folic acid is a precursor to the effective vitamin form. Folic acid is partly transformed in the mucosa cell to dihydrofolate (DHF) and tetrahydrofolate (THF) and later in the liver to 10-formyl-THF and 5,10methylene-THF. MTHFR catalyzes the transformation of 5,10methylene-THF into 5-MTHF. ${ }^{13}$ A decrease in the methylation cycle is expressed in elevation of plasma total homocysteine (tHcy), or hyperhomocysteinemia (HHCY). HHCY can be inherited, i.e. genetic polymorphisms of MTHFR or acquired, i.e. folate and/or vitamin $\mathrm{B}_{6} / \mathrm{B}_{12}$ deficiencies due to deregulation of their normal metabolism and/or low dietary intake. ${ }^{14-18}$ As an example, homozygous genotypes with the C677T-MTHFR-polymorphism are 75\% less active, when a point mutation at nucleotide 677 causes the replacement of cytosine with thymine. Insufficient 5-MTHF increases homocysteine because of inadequate re-methylation of homocysteine into methionine. ${ }^{19}$ Indeed, Hcy, which is neurotoxic, is metabolized by re-methylation by homocysteine methyl transferase, requiring 5-MTHF and vitamin $\mathrm{B}_{12}$. Another Hcy elimination

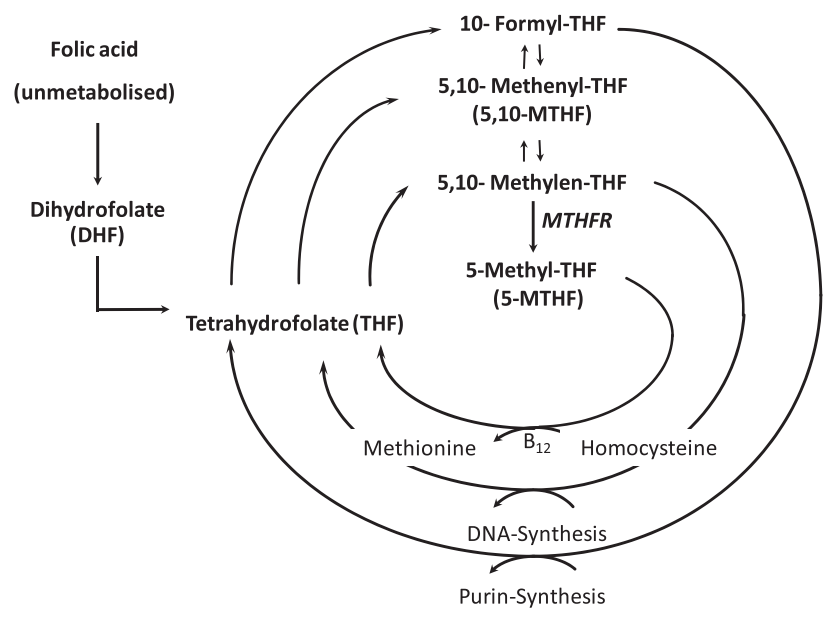

Fig. 1. Overview of one-carbon metabolism. Modified from K. Pietrzik, I. Golly, D. Loew, Handbuch Vitamine, Elsevier Urban \& Fischer 2008. ${ }^{12}$ Folic acid is partly transformed in the mucosa cell to dihydrofolate (DHF) and tetrahydrofolate (THF) and later in the liver to 10-formyl-THF and 5,10-methylene-THF. Methylenetetrahydrofolate reductase (MTHFR) catalyzes the transformation of 5,10-methylene-THF into 5-MTHF. ${ }^{13}$ Vitamin B12 is essential for the conversion of 5-MTHF to 5,10-methylene-THF and, consequently, for the methylation cycle and the biosynthesis of DNA and RNA. route is the trans-sulfuration pathway, where the conversion from homocysteine to cysteine takes place in two enzymatic steps, each of which involves vitamin $\mathrm{B}_{6}$ as a coenzyme. ${ }^{20}$

\subsubsection{Folic acid intake during pregnancy}

Folate needs increase substantially in pregnancy owing to the enlargement of the uterus, the development of the placenta, and the increasing red cell volume of the mother, as well as the growth of the developing fetus. There is consistent scientific evidence that folic acid is of critical importance both pre- and periconceptionally in protecting the fetus from neural tube defects (NTDs). ${ }^{21}$ Estimated folate requirements increase by $50 \%$ to $600 \mu \mathrm{g} / \mathrm{day}$ during pregnancy, and even if the daily diet consists of food rich in folates, the high requirement usually cannot be met through the consumption of unfortified foods alone. For this reason, internationally, periconceptional supplementation of $400 \mu \mathrm{g} /$ day of folic acid is recommended for prevention of NTDs. Periconceptional supplementation of $800 \mu \mathrm{g} /$ day of folic acid combined with multivitamins achieved a near $100 \%$ reduction of NTDs as well as marked reductions of congenital heart defects. ${ }^{22-24}$ Daly et al. ${ }^{25}$ found that red cell folate levels higher than $906 \mathrm{nmol} / \mathrm{L}$ are associated with maximal risk reduction of NTDs. In 1998 the German Nutritional Survey evaluated folate concentrations in serum and in red cells of women of childbearing age. Only $13 \%$ of the women showed a red cell folate level higher than $906 \mathrm{nmol} / \mathrm{L} .{ }^{26}$ With a daily dosage of $800 \mu \mathrm{g}$ folic acid, the preventive red blood cell level of $906 \mathrm{nmol} / \mathrm{L}$ is reached within an average 4 weeks after the start of supplementation ${ }^{27}$ (Fig. 2). In contrast, the current recommendation to supplement $400 \mu \mathrm{g}$ folic acid daily starting at least 4 weeks before conception is not enough to achieve optimal red cell folate levels within 4 weeks; this requires at least 8-12 weeks of daily intake. ${ }^{28}$ Though there might be an adaptation to increase absorption of nutrients during pregnancy, optimal folate levels have to be achieved around conception as the neural tube closes between 23rd and 27th day of pregnancy. Thus, if one wishes to maintain the current recommended supplementation period of 4 weeks before pregnancy, it may be preferable to increase the folic acid dosage to $800 \mu \mathrm{g}$ to achieve a maximal preventive effect associated with a red cell folate level of greater than about $900 \mathrm{nmol} / \mathrm{L}$. Maternal folic acid intake also correlates with birthweight, ${ }^{29}$ which may be explained through the role of folate in nucleic acid synthesis. Moreover, associations between maternal folate status and pathological changes in the placenta have been

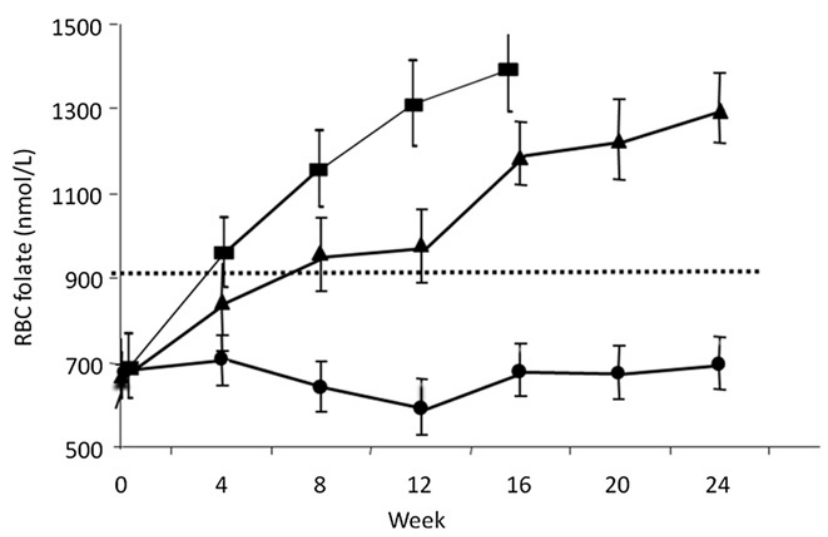

Fig. 2. Change in red blood cell (RBC) folate concentration ( $\mathrm{nmol} / \mathrm{L}$ ) of childbearing women after a dosage of $800 \mu \mathrm{g}(\boldsymbol{\square})$ and of $400 \mu \mathrm{g}(\boldsymbol{\Delta})$ folic acid per day over a long period of time. Placebo ( ) was also considered. Blotted line indicates the lower RBC folate level $(906 \mathrm{nmol} / \mathrm{L})$ required as an optimum risk reduction of neural tube defects (NTDs). Modified from K. Pietrzik, I. Golly, D. Loew, Handbuch Vitamine, Elsevier Urban \& Fischer 2008. ${ }^{12}$ 
reported (abruption placenta, infarct of the placenta), as well as with spontaneous abortion. These associations are also evident for homocysteine levels. ${ }^{30-33}$ Interestingly, an increased risk of NTDs was associated with a high prevalence of a genetic variant in the pathway of homocysteine metabolism causing HHCY. ${ }^{13,34}$ Results from this study showed that the incidence of NTDs not only correlates with the supply of folate but also that of vitamin $B_{12}$. Women with a low folate supply combined with low blood vitamin $B_{12}$ levels have a drastically increased risk of NTDs. Vitamin $B_{12}$ is involved in homocysteine metabolism being a coenzyme of the methionine synthase and acting as a 5-MTHF methyl group donor from methylcobalamine to homocysteine. Biochemically, vitamin $\mathrm{B}_{12}$ and 5-MTHF are closely linked in regard to homocysteine remethylation. Thus, an increased tHcy level could be a causal factor for NTD occurrence. These findings raise the potential that the most effective periconceptional prophylaxis to prevent NTDs could be the provision of both folic acid and vitamin $\mathrm{B}_{12}$. A meta-analysis of randomized trials demonstrated that daily supplementation with both $0.5-5.0 \mathrm{mg}$ folic acid and $0.5 \mathrm{mg}$ vitamin $\mathrm{B}_{12}$ can reduce blood homocysteine concentrations by about a quarter to a third. ${ }^{35}$ In particular, a folic acid dose of $800 \mu \mathrm{g}$ was shown to have optimal dosage with respect to lowering Hcy levels. ${ }^{36}$ It is possible that the biological potential of folate might be even higher by using 5-MTHF supplements, since significantly higher red blood cell folate levels were achieved by 5-MTHF in the form of calcium-L-methylfolate compared to folic acid supplementation. ${ }^{28}$ Given that not only an increased risk for NTDs ${ }^{37}$ but also various complications during pregnancy such as abruptio placenta, placenta infarction and spontaneous abortions are associated with MTHFR-polymorphism, ${ }^{38-40}$ provision of 5-MTHF might optimize the benefits of the folate supply.

\subsubsection{Folic acid and public health measures}

Even though the importance of periconceptional folic acid supplementation for prevention of NTDs has been widely acknowledged and supported by both scientific and governmental recommendations throughout the world, its implementation is less than satisfactory. Folate supplementation should be recommended for all women who might become pregnant, and public health measures should be taken to ensure that the diet of all women who may bear children is enriched with an adequate amount of folic acid. The current recommendation to supplement $400 \mu \mathrm{g}$ of folic acid at least 4 weeks before conception and in the first trimester of pregnancy should be re-assessed, particularly in areas where a general food fortification policy has not yet been implemented. Currently, more than 50 countries worldwide have national regulations for mandatory wheat-flour fortification with folic acid. In response to fortification there was a $26 \%$ risk decline of NTDs in the US and approximately $46 \%$ in Canada with higher reductions in high risk provinces (e.g. $-78 \%$ in Newfoundland). Data from other countries support the benefit of those regulations. However, no European country has yet developed national regulations for mandatory folic acid fortification. The discussion on fortification remains controversial because of concerns regarding potential risks of chronic exposure to high-dose folic acid. ${ }^{41}$ The safety of very high intakes of folic acid is really unknown, so the Institute of Medicine recommends a tolerable upper intake level for folic acid of $1 \mathrm{mg} /$ day for adults. ${ }^{42}$ Specifically, high doses of folic acid are suggested to mask anemia caused by vitamin $\mathrm{B}_{12}$ deficiency thus leading to delayed diagnosis of neurological symptoms. ${ }^{43,44}$ Moreover, the issue of folate and risk of cancer has received much public health attention as a result of a potential dual role of folic acid in carcinogenesis. It seems that folic acid supplementation prevents the development of tumors in normal tissues, whereas it accelerates the development and progression of already growing neoplasms. ${ }^{41}$
The timing and the dose of folate intervention appears to be responsible for this dual modulatory role of folate in carcinogenesis. However, evidence from randomized trials is lacking and inconclusive, consequently further investigations are needed in this field. ${ }^{45}$ Similar discrepancies have been reported regarding the adverse effects of folic acid on zinc absorption, as some authors observed a significantly decreased zinc absorption when pregnant women received $350 \mu \mathrm{g} /$ day iron-folic acid supplement for 2 weeks. ${ }^{46}$ Nevertheless, a 12 -wk placebo-controlled trial failed to detect any adverse effect of $400 \mu \mathrm{g} /$ day folic acid supplementation on zinc absorption. ${ }^{47}$

\subsection{Antioxidants}

Reactive oxygen species (ROS), reactive nitrogen species and reactive chlorine species are synthesized in humans and animals under physiological and pathological conditions. ${ }^{48}$ ROS oxidize biomolecules such as DNA, lipids, proteins, leading to cell injury and death. ROS are involved in female reproduction, in such physiological processes as the endometrial cycle, luteolysis, implantation, embryogenesis, and in pregnancy. ${ }^{49,50}$ An imbalance in the equilibrium of pro-oxidants and antioxidants can result in oxidative damage (OS), a key element in the pathogenesis of several diseases. ${ }^{51}$ Antioxidants maintain homeostasis via effects on redox status and/or redox-sensitive signaling pathways and gene expression. ${ }^{52}$ By contributing directly and indirectly to antioxidant defense, antioxidants enhance many aspects of the immune response and limit pathological aspects of the cytokine-mediated response. ${ }^{48}$ Many antioxidants are derived from the diet, such as vitamin $\mathrm{E}$ and other tocopherols, vitamin $\mathrm{C}, \beta$-carotene, whereas proteins and peptides, such as glutathione (GSH), ceruloplasmin, and metallothionein are synthesized endogenously. ${ }^{53,51}$ Other micronutrients such as magnesium, copper, zinc, manganese and selenium are involved in antioxidant defense as cofactors of enzymes (i.e., copper-selenium-zinc in superoxide dismutase (SOD), selenium in GSH peroxidase). ${ }^{48}$

The demands of normal pregnancy, especially during the third trimester and at parturition, impose considerable systemic oxidative, metabolic and inflammatory stress. ${ }^{54}$

\subsubsection{Oxidative and inflammatory stress and the onset of preeclampsia}

Preeclampsia remains a frequent and potentially dangerous complication of pregnancy, affecting $2-5 \%$ of pregnant women worldwide, and it is a major cause of maternal death. ${ }^{55}$ As delivery is the only known cure, and because it can occur from 20 weeks of gestation onwards, preeclampsia can also lead to preterm delivery, contributing to high neonatal mortality and morbidity. Thus, preeclampsia is associated with both a maternal and a fetal syndrome. The maternal syndrome of preeclampsia has previously been ascribed to generalized maternal endothelial cell dysfunction. However, the endothelial dysfunction is part of a more generalized intravascular inflammatory reaction involving intravascular leukocytes as well as the clotting and complement systems. ${ }^{54}$ In preeclampsia both systemic oxidative stress and inflammatory state are significantly enhanced as part of the maternal syndrome. The condition evolves in two stages (Fig. 3): stage 1 occurs without symptoms in the first half of pregnancy, due to poor placentation. This causes an abnormally high pressure and pulsatile uteroplacental blood that induces oxidative stress and increased synthesis and release of pro-inflammatory factors. During placentation, trophoblast-cell invasion into the placental bed is inadequate, with deficient remodeling to enlarge the spiral arteries. ${ }^{56}$ The disturbed pattern of blood flow leads to reduced growth of the branches of the placental villous tree, namely the narrow muscular arteries 


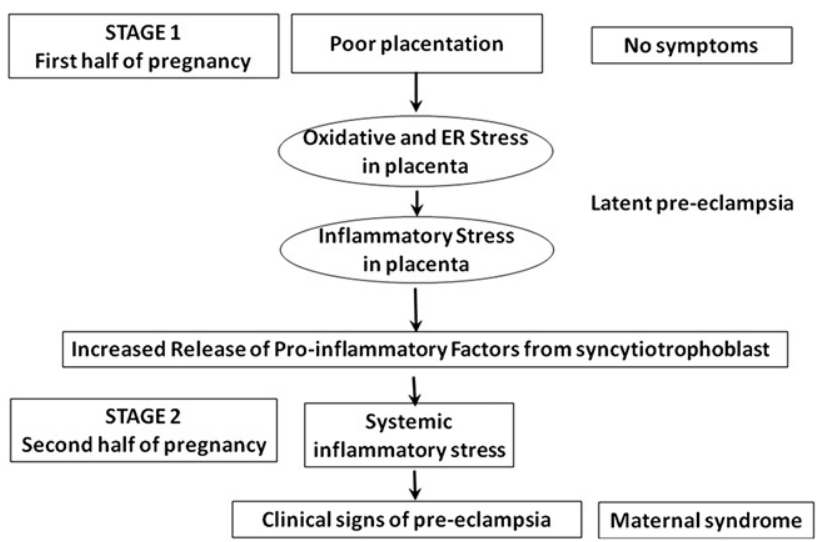

Fig. 3. Stages and factors involved in preeclampsia onset and development. ER: Endoplasmic reticulum.

which perfuse lobules intermittently. Numerous studies suggest that the "preeclamptic" oxidative stress arises from hypoxia/reperfusion. ${ }^{57}$ These include the demonstration of increased activity of enzymatic pathways leading to superoxide generation, direct measurement of free radical synthesis, activation of downstream signaling pathways and evidence of enhanced lipid peroxidation. Increased expression of stress response genes including heme oxygenase 1 provides further support to this hypothesis. The placenta appears to be the principal source of free radical synthesis but maternal leukocytes and the maternal endothelium are also likely contributors. Recent reports have suggested an important role for placental trophoblast $\mathrm{NAD}(\mathrm{P}) \mathrm{H}$ oxidase in free radical generation in preeclampsia. ${ }^{55,58}$ Stage 2 preeclampsia presents at any time in the second half of pregnancy with the typical clinical signs, and is characterized by systemic inflammatory stress. Preeclampsia may be associated with fetal growth restriction, because the damaged placenta has a reduced functional capacity.

Maternal health status and dietary factors may affect the occurrence of preeclampsia. Chronic arterial and metabolic diseases such as hypertension, obesity, type 2 diabetes and metabolic syndrome are risk factors for preeclampsia. However, the mechanisms by which obesity may cause gestational diabetes and hypertensive disorders of pregnancy is still under investigation. ${ }^{59}$ Several possibilities include the adverse effects of insulin resistance, elevated cholesterol and elevated leptin levels on blood pressure. Moreover, in pregnancy the placenta is the primary source of leptin. ${ }^{60}$ Remarkable increases in fetal and placental leptin levels have been associated with preeclampsia. Leptin and immune function are linked, ${ }^{61}$ and in particular leptin has a proinflammatory role. Adipose tissue is a source of several other inflammatory factors besides leptin (for example interleukins-1, -6 and tumor necrosis factor alpha), complement factors and components of the coagulation/fibrinolytic cascade. IL-6 stimulates C-reactive protein synthesis which is positively correlated with obesity, insulin resistance, elevated TNF- $\alpha$ and endothelial dysfunction. ${ }^{62}$ Low grade systemic inflammatory activation is typical of preeclampsia but the extent to which leptin, presumably of placental origin, contributes is still not known. Diet may also be relevant. Both excessive eating and consuming a poor quality diet are associated with more systemic inflammatory stress. In the nonpregnant state, meals and especially fat rich meals cause transient inflammatory stress ${ }^{63,64}$ which may be sustained if the intervals between meals are short.

\subsubsection{Role of antioxidants in preeclampsia}

Some nutrients may protect against preeclampsia. Calcium supplementation has been reported to reduce the incidence of preeclampsia, particularly in geographic regions with low calcium intakes. ${ }^{65}$ Although the mechanism is obscure, supplements may be assumed to increase chylomicron clearance after meals ${ }^{66}$ which could reduce postprandial inflammatory stress.

Omega-3 long chain PUFA may also attenuate inflammatory responses. However, the evidence from human studies is inconsistent if not conflicting. ${ }^{67}$ There is no conclusive evidence that supplementation of omega-3 long chain PUFA would be beneficial for preventing preeclampsia ${ }^{68}$ and some data even suggest a risk increasing effect. ${ }^{69}$

The antioxidant vitamin $\mathrm{E}$ is known to have multiple actions in addition to preventing lipid peroxidation, including inhibition of $\mathrm{NAD}(\mathrm{P}) \mathrm{H}$ oxidase activation and the inflammatory response. ${ }^{70}$ Given the abnormally low plasma vitamin C concentrations reported in preeclampsia, a combination of vitamins $\mathrm{C}$ and $\mathrm{E}$ has been postulated as a prophylactic strategy for prevention of preeclampsia. ${ }^{71}$ However, there is no evidence that high doses of vitamin C and vitamin E (1000 $\mathrm{mg}$ and $400 \mathrm{IU}$, respectively) combined reduce the occurrence of preeclampsia. ${ }^{72}$ In particular, some randomized controlled trials involving a large number of pregnant women have shown a lack of benefit in women receiving antioxidants, ${ }^{73-76}$ as reported in Table 1 . Therefore, the use of such high-dose antioxidants cannot be justified in pregnancy.

Table 1

Characteristics and results from randomized controlled trials intervention studies indicating no effects on preeclampsia of high doses of vitamin C and Vitamin $\mathrm{E}$ (1000 mg and $400 \mathrm{IU}$, respectively) combined.

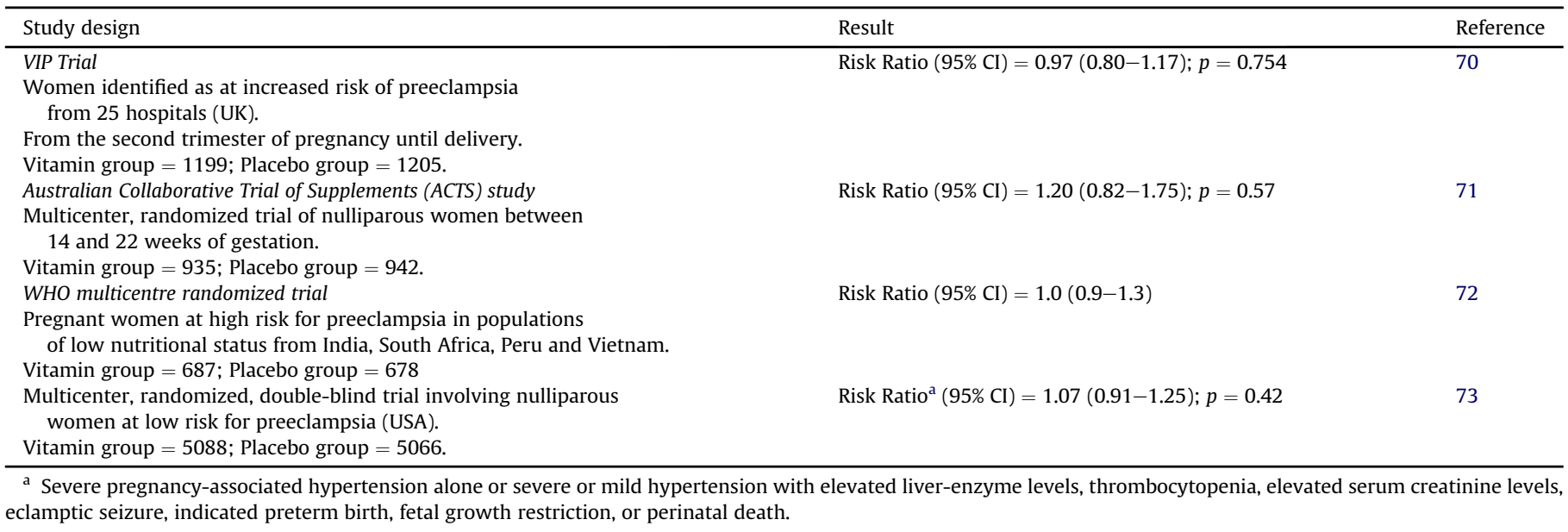


These trial results add to the broader literature in cardiovascular medicine where antioxidant supplements generally have no effect on the progression of cardiovascular disease, despite good evidence for an association of these disorders with biomarkers of oxidative stress. Whether these trials suggest that oxidative stress is not part of the pathogenesis of preeclampsia or the dose or the choice of antioxidant prophylaxis is inappropriate, is unknown. The susceptibility to oxidative stress of erythrocytes has been found to be increased in preeclampsia as early as $14-20$ weeks gestation prior to onset of the clinical disease. ${ }^{77}$ This depended on glucose-6phosphate dehydrogenase (G6PD) activity, essential to maintain intracellular NADPH activity, which was lower in preeclamptic pregnancies compared to controls and unaffected by antioxidant treatment with vitamins $C$ and $E$. These findings provide the first evidence that decreased G6PD activity in preeclampsia causes impaired redox regulation in erythrocytes and might explain why antioxidant vitamin C/E supplementation in the VIP trial did not protect from preeclampsia. ${ }^{77}$

Selenoenzymes play a critical role in regulating antioxidant status, through the selenoproteins such as GSH peroxidases (GPx). GPx removes the products of reactions with hydroperoxides and oxidized lipoproteins, limiting adverse effects on the endothelium. It is therefore of some interest that a poor maternal selenium (Se) status may be a predictor of preeclampsia, given that women who develop overt preeclampsia have a lower Se status. ${ }^{78}$ Vanderlelie et al. ${ }^{79}$ studied the tissue levels of endogenous antioxidant proteins (SOD, GHS peroxidase, thioredoxin reductase and thioredoxin) and of lipid and protein oxidation in placental samples from normal and preeclamptic pregnancies and found a decreased enzymatic antioxidant capacity in placental tissue from preeclamptic women compared to controls. Highly significant reductions in serum Se concentrations and plasma GSH peroxidase activity were found in pregnancy per se compared to non-pregnant subjects. ${ }^{80}$ However, even lower levels were found in preeclamptic mothers and their babies. Subsequently, both preeclamptic mothers and their infants had significantly increased levels of oxidative stress-markers and reduced placental GSH peroxidase activity. In rats, low Se intake causes a preeclampsia-like syndrome ${ }^{81}$ which is consistent with the human observations. Oxidative stress related to preeclampsia might be a consequence of reduced antioxidant defense pathways due to reduced Se availability. Reduced GPx may be related to increased generation of toxic lipid peroxides contributing to the endothelial dysfunction and hypertension of preeclampsia.

\subsection{Vitamin $A$}

Vitamin $A$ is obtained from the diet either as pre-formed vitamin $A$ in the form of retinol or retinyl-esters, or as provitamin A-carotenoids. The highest content of pre-formed vitamin A is found in liver and liver oils of marine animals. Yellow and green leafy vegetables provide significant amounts of provitamin Acarotenoids. ${ }^{82}$ However, high doses ( $<6 \mathrm{mg} /$ day) of provitamin $\mathrm{A}$ are needed to substitute pre-formed retinol. ${ }^{83}$ Retinol is the endogenous metabolite and retinoic acid is the morphogenetically active compound. Vitamin A plays a key role in ocular retinoid metabolism and visual function as well as in cellular differentiation, related to embryonic development in particular lung maturation and immunity. Carotenoids exert antioxidant properties.

Fetal and neonatal vitamin A status depends on maternal vitamin A status. Fetal/neonatal synthesis of retinol binding protein is not sufficient to ensure continuous supply from liver stores. Hence, an adequate maternal vitamin A supply is essential to ensure normal fetal growth and development. ${ }^{11}$ The Recommended Daily Allowance (RDA), that is the amount of vitamin A that should be taken to prevent vitamin deficiency, is about $0.8 \mathrm{mg} /$ day. ${ }^{84} \mathrm{~A}$ large heterogeneity, however, exists with recommended intakes varying from $0.77 \mathrm{mg} /$ day in $\mathrm{UK}^{85}$ to $1.1 \mathrm{mg} /$ day in D-A-CH countries. ${ }^{86}$ Vitamin A deficiency during pregnancy seems to be associated with preterm birth, LBW and low neonatal liver stores. ${ }^{87-90}$ Low vitamin A status of the newborn appears to contribute to the risk for bronchopulmonary dysplasia (chronic lung disease). Low neonatal liver stores and a low supply during lactation also appear to increase the risk for infection. ${ }^{90}$

The German Nutrition Society (DGE) recommends a $40 \%$ increase in vitamin A intake for pregnant women and a $90 \%$ increase for breastfeeding women. The American Academy of Pediatrics Committee on Nutrition (1998) ${ }^{91}$ cites vitamin A as one of the most critical vitamins during pregnancy and the breastfeeding period, especially in terms of lung function and maturation. If the mother has suboptimal intake, her supply to fetus will be inadequate, as will later the vitamin A content of her milk. These inadequacies cannot be rectified by postnatal supplementation. A clinical study in pregnant women with short birth intervals or multiple births showed that almost $1 / 3$ of the women showed plasma retinol levels below $1.4 \mu \mathrm{mol} / \mathrm{L}$ which can be taken as borderline deficiency. ${ }^{92}$ Despite the fact that vitamin A and betacarotene rich food is generally available, risk groups for low vitamin A supply exist in the western world.

Even though $25 \%$ of the population have an inadequate retinol supply ${ }^{93}$ pregnant women are routinely advised against consumption of liver, the major dietary source of pre-formed vitamin A. This advice is based on two main considerations. The first is that there is no doubt that synthetic retinoids, used for the treatment of severe acne are teratogenic. ${ }^{94}$ Secondly there are case reports of teratogenicity associated with high-dose supplementation with, or overdose of, vitamin A. This raises the question which source of vitamin A supply in pregnancy and lactation can be considered adequate and safe. Alternative strategies to augment maternal vitamin A status are either selective supplementation with retinol, or supplementation/fortification with isolated $\beta$ carotene. However, the conversion of $\beta$-carotene to retinol may be limited and varies with genetic polymorphisms frequently found in the population. ${ }^{95}$ Excessive dietary intake has been associated with teratogenicity in humans in 20 reports published until 1986, and no further reports since that time. ${ }^{94}$ However, there is a lack of adequate data on a teratogenic effect of pre-formed vitamin A (retinol or retinylester). ${ }^{96}$ In particular there are no data showing any relationship between consumption of liver and malformations. Nevertheless, a daily intake of more than $3 \mathrm{mg}$ pre-formed Vitamin A (10,000 IU) should be avoided by women who are or who might become pregnant based on a precautionary principle. ${ }^{11}$ During the first trimester of pregnancy vitamin A intake from liver or supplements is not recommended. However, especially during the third trimester, sufficient vitamin A intake that is $100-150 \%$ RDA is strongly recommended to ensure sufficient neonatal liver and lung stores of vitamin A for adequate tissue maturation. ${ }^{1}$

\subsection{Vitamin $D$}

Over the past decade observational studies in non-pregnant individuals have associated low 25-OH-vitamin D levels in plasma with an increased risk of various common chronic diseases such as colon, breast and prostate cancer, metabolic syndrome, hypertension, multiple sclerosis, type I diabetes, and inflammatory bowel disease, even though causality has not been firmly established. ${ }^{97}$ In addition to its action on calcium metabolism and bone homeostasis, there are other physiologic systems in which vitamin $D$, the steroid hormone, 1,25-dihydroxyvitamin D (1,25[OH]2D), and its receptor generate biological responses. ${ }^{98}$ For example, $1,25[\mathrm{OH}] 2 \mathrm{D}$ inhibits parathyroid hormone (PTH) secretion but promotes insulin 
secretion, it inhibits adaptive immunity but promotes innate immunity. So vitamin D appears to exert anti-inflammatory and anti-microbial activity through the innate immune system and to inhibit cell proliferation while stimulating cell differentiation. ${ }^{99}$

Estimates of the prevalence of vitamin D deficiency or insufficiency vary greatly depending on the chosen cut-offs for serum 25hydroxyvitamin D (25[OH]D) concentrations. ${ }^{100,101}$ Indeed, the threshold for optimal 25[OH]D concentration could vary with regards to the expected effects, which may relate to bone health but also to the non-classical actions of vitamin D on maternal and fetal outcomes. In Australia and New Zealand currently a dietary vitamin D intake for pregnant women of $200 \mathrm{IU} /$ day has been recommended $^{102,103}$ while $400 \mathrm{IU} /$ day are recommended in the United Kingdom ${ }^{104}$ and $600 \mathrm{IU} /$ day in the United States and Canada. ${ }^{105}$ Basing adequate intake allowances of vitamin D on vitamin D's actions on calcium and bone tissues is the subject of widespread controversy. ${ }^{106,107}$ Given the evolving concept of vitamin D-sufficiency, it is currently considered that sufficiency may be defined by a serum $25[\mathrm{OH}] \mathrm{D}$ levels $>75 \mathrm{nmol} / \mathrm{L}^{100}$ By this criterion, the prevalence of vitamin $D$ insufficiency during pregnancy could be as high as $70 \%$ in western countries. ${ }^{108}$ The related potential public health implications warrant attention.

Recent surveys confirm that 25[OH]D concentrations in pregnant women are not different from those of non-pregnant women and are significantly associated with ethnicity. ${ }^{109,110}$ Vitamin D deficiency is more common in dark-skinned individuals living in northern countries where sunlight is less effective in producing vitamin D3 $(1,25[\mathrm{OH}] 2 \mathrm{D})$ in darker skin because the ultraviolet light is absorbed by the skin pigment. In addition, low sunlight exposure, the habit of covering the skin, and a diet low in vitamin D and calcium may all contribute to lower vitamin D concentrations in non-Western immigrants to northern countries. ${ }^{111,112} \mathrm{~A}$ study in pregnant women of several ethnic backgrounds living in The Hague (the Netherlands) showed that mean serum 25[OH]D concentrations were significantly lower in women of Turkish, Moroccan, and other non-Western groups than those in Western women. ${ }^{110} \mathrm{~A}$ comparison of the observed serum 25[OH]D concentrations in the population of the USA measured in the NHANES III (1988-1994) and NHANES 2000-2004 studies suggests an overall decline in vitamin D status over the past $10-15 \mathrm{y}{ }^{109}$

Vitamin D status may be critical with regards to pregnancy and fetal/infant outcomes. ${ }^{13}$ Severe vitamin D deficiency causes modest hypocalcemia and secondary hyperparathyroidism and osteomalacia in non-pregnant adults, but no reports have documented worsening during pregnancy. ${ }^{114}$ Despite the significantly higher needs of calcium to be passed on to the developing fetus, maternal adaptations provide the necessary calcium relatively independent of vitamin D status. Table 2 presents observational studies addressing the association between poor pregnancy outcomes and vitamin D. ${ }^{115-120}$ Vitamin D deficiency seems to be associated with an increased risk of preeclampsia. The pathogenesis of preeclampsia involves several biological/molecular pathways that may be affected by vitamin $\mathrm{D}$, including placental dysfunction/insufficiency, abnormal angiogenesis, excessive inflammation, and hypertension. ${ }^{121-124}$ However, a recent study showed no association between vitamin D deficiency and preeclampsia $^{125}$ to suggest that low serum vitamin D levels in preeclampsia do not necessarily indicate dietary deficiencies but may be a consequence of placental dysfunction or a secondary consequence of systemic inflammation. The placenta synthesizes active $1,25[\mathrm{OH}] 2 \mathrm{D}$ from its precursor. ${ }^{125-127}$

A possible role of vitamin $\mathrm{D}$ in maintaining normal glucose homeostasis is discussed in the review by Peechakara et al. ${ }^{128}$ In both animal and human studies, vitamin D depletion appears to be associated with insulin resistance and impaired insulin secretion. ${ }^{129}$ In particular, a significant and strong association between

Table 2

Studies examining the association between vitamin D status and diabetes or preeclampsia.

\begin{tabular}{|c|c|c|c|}
\hline Outcome & Study Design & Result & Reference \\
\hline \multirow[t]{4}{*}{$\begin{array}{l}\text { Vitamin D deficiency } \\
\text { and preeclampsia }\end{array}$} & $\begin{array}{l}\text { Case-control study of pregnant women followed } \\
\text { from less than } 16 \text { wk gestation to delivery. } \\
\text { Nulliparous pregnant women who developed } \\
\text { preeclampsia }(n=55) \text { or did not develop } \\
\text { preeclampsia }(n=219)\end{array}$ & $\begin{array}{l}\text { Adjusted serum } 25[\mathrm{OH}] \mathrm{D} \text { concentrations in early } \\
\text { pregnancy } 15 \% \text { lower in women who subsequently } \\
\text { developed preeclampsia compared with controls. } \\
\text { Adjusted odds ratio }(95 \% \mathrm{CI})=2.4(1.1-5.4)\end{array}$ & 115 \\
\hline & $\begin{array}{l}\text { Longitudinal study included } 170 \text { healthy } \\
\text { normotensive pregnant women. During the study, } \\
160 \text { women remained NT and } 10 \text { developed } \\
\text { preeclampsia at the third gestational period }\end{array}$ & $\begin{array}{l}\text { Circulating levels of } 1,25-[\mathrm{OH}] 2 \mathrm{D} \text { not altered in } \\
\text { women before they developed preeclampsia. }\end{array}$ & 116 \\
\hline & $\begin{array}{l}\text { Thirty-two patients with preeclampsia and } 20 \\
\text { normotensive women with singleton gestations } \\
\text { in the third trimester. }\end{array}$ & $\begin{array}{l}\text { Increased bone resorption and decreased bone } \\
\text { formation occur in preeclampsia in both mother } \\
\text { and fetus. }\end{array}$ & 117 \\
\hline & & $\begin{array}{l}\text { Normal pregnancy: maternal coupling index }(\mathrm{CI}) \\
\text { of markers of bone turnover }=+3.28 \text {; fetal } \mathrm{CI}=+11.8 \text {. } \\
\text { Mild preeclampsia: maternal } \mathrm{CI}=+1.4 \text {; fetal } \mathrm{CI}=-30.85 \text {. } \\
\text { Severe preeclampsia: maternal } \mathrm{CI}=-25.71 \text {; fetal } \\
\mathrm{CI}=-70.02\end{array}$ & \\
\hline \multirow[t]{3}{*}{$\begin{array}{l}\text { Vitamin D deficiency } \\
\text { and insulin resistance }\end{array}$} & $\begin{array}{l}\text { Nested case-control study among a prospective } \\
\text { cohort of } 953 \text { pregnant women (Omega Study). } \\
\text { Incident GDM cases ( } n=57) \text { and women who } \\
\text { were not diagnosed with GDM }(n=114)\end{array}$ & $\begin{array}{l}\text { Each } 5 \mathrm{ng} / \mathrm{ml} \text { decrease in } 25[\mathrm{OH}] \mathrm{D} \text { concentrations } \\
\text { was related to a } 1.29 \text {-fold increase in GDM risk. } \\
\text { Odds ratio }(95 \% \mathrm{CI})=1.29(1.05-1.6)\end{array}$ & 118 \\
\hline & $\begin{array}{l}\text { Prospective study a convenience sample of } 307 \\
\text { pregnant women. }\end{array}$ & $\begin{array}{l}\text { Significant linear associations were therefore found } \\
\text { between log-transformed 25[OH]D and fasting } \\
\text { glucose, fasting insulin and HOMA-insulin resistance }\end{array}$ & 119 \\
\hline & $\begin{array}{l}\text { Cross-sectional study was conducted on } 741 \text { pregnant } \\
\text { women with no previous history of diabetes mellitus }\end{array}$ & $\begin{array}{l}\text { Prevalence of severe vitamin D deficiency in GDM } \\
\text { patients higher than in normoglycaemic pregnancies. } \\
25[\mathrm{OH}] \mathrm{D} \text { levels: GDM pregnancies } \\
=(16.49 \pm 10.44) \text { vs normal pregnancy } \\
=(22.97 \pm 18.25) ; p=0.009 \text {. } \\
\text { Strong correlation between the HOMA index } \\
\text { and serum levels of vitamin D. }\end{array}$ & 120 \\
\hline
\end{tabular}


vitamin $D$ deficiency and $\beta$-cell dysfunction has been reported in 126 healthy, glucose-tolerant subjects. ${ }^{130}$ Moreover, some studies have found a significant association between maternal plasma 25 $[\mathrm{OH}] \mathrm{D}$ concentrations in early pregnancy and the risk for gestational diabetes mellitus (GDM), fasting glucose levels or the Homeostasis Model Assessment (HOMA) index ${ }^{118-120}$ (Table 2).

\subsubsection{Fetal and infant outcomes}

Maternal vitamin D deficiency predisposes newborns to neonatal hypocalcaemia, and to later rickets. Observational studies also suggest that the bone mass of the newborn is related to the vitamin D status of the mother (reviewed by Salle et al. ${ }^{131}$ ). In a longitudinal study, it has been reported that children at 9.5 years of age born to vitamin D-deficient (serum 25[OH]D concentration $<50 \mathrm{nmol} / \mathrm{L})$ mothers $(n=379)$ had significantly smaller armmuscle area in comparison with children born to mothers without deficiency $(n=189){ }^{132}$ Moreover, several studies propose low vitamin D concentrations during prenatal or early life development as a cause of a greater risk of later development of multiple sclerosis, cancer, insulin dependent diabetes mellitus, and schizophrenia. ${ }^{114}$ There is growing evidence that in rodents vitamin D deficiency during pregnancy may disrupt fetal brain development and may lead to persistent changes in the adult brain. ${ }^{133}$ The absence of vitamin D during fetal development on protein expression in the adult brain was studied in pregnant female rats kept vitamin D-deficient until birth. ${ }^{97}$ At week 10 , protein expression in the progeny's prefrontal cortex and hippocampus was compared with control animals. Developmental vitamin D deficiency caused a dysregulation of 36 brain proteins involved in several biological pathways including oxidative phosphorylation, redox balance, cytoskeleton maintenance, calcium homeostasis, chaperoning, PTMs, synaptic plasticity and neurotransmission. A computational analysis of data revealed that nearly half of the deregulated molecules have also been shown to be misexpressed in either schizophrenia and/or multiple sclerosis. Moreover, in rats a clinical phenotype was induced characterized by hyperlocomotion in the offspring at adult age. ${ }^{134} \mathrm{~A}$ recent meta-analysis shows that the risk of type 1 diabetes is significantly reduced in infants who were supplemented with vitamin D compared to those who were not supplemented suggesting that Vitamin D supplementation in early childhood may offer protection against the development of type 1 diabetes. ${ }^{135}$ During pregnancy, few observational studies suggest that vitamin $D$ insufficiency is associated with childhood incidence of type 1 diabetes [adjusted odds ratio (95\% CI): $0.74(0.56,0.99)] .{ }^{136}$ There are also arguments that low maternal vitamin D intake may be associated with the risk of recurrent wheeze at 3 or 5 years which suggests that childhood asthma may be influenced by maternal diet during pregnancy. ${ }^{137,138}$ For an example, mothers consuming high daily intakes (median: $724 \mathrm{IU}$ ) during pregnancy had a lower risk of having a child with recurrent wheeze at 3 years of age [odds ratio (95\% CI): $0.39(0.25$, $0.62), p<001$ ] with respect to mothers in the lowest quintile of daily intakes (356 IU). ${ }^{137}$ On the whole, the available data suggest that vitamin D status during pregnancy is not only linked to maternal skeletal health and fetal skeletal formation but also may affect maternal outcomes and longer term health of the child, ${ }^{139}$ and that the high risk of developing diseases characterized by systemic inflammation may be attributable to vitamin $\mathrm{D}$ antiinflammatory properties. ${ }^{99}$ However, there are too few relevant studies to form a strong evidence base, mostly because of small sample size, and because the majority are observational. Further evidence from appropriately designed interventional trials is required. Additional studies are also needed to determine optimal $25[\mathrm{OH}] \mathrm{D}$ concentrations with regards not only to bone health but also to non-classical actions of vitamin D on maternal and fetal outcomes. Vitamin D-deficient or insufficient neonates are at risk of hypocalcaemia and rickets, and recommendations to support an adequate $25[\mathrm{OH}] \mathrm{D}$ status of women during pregnancy might thus be best directed toward ensuring vitamin D-sufficiency in the newborn. Unfortunately, there is a lack of consensus on the thresholds of maternal and neonatal plasma 25[OH]D that define the lower limit of adequacy or sufficiency, and international dietary recommendations for dietary vitamin D intake vary considerably. Considering the contrasting opinions on increasing of vitamin D intake recommendations ${ }^{140}$ and the limited data on the biological effects, monitoring of effects with higher intakes of vitamin D should be promoted.

\subsection{Iron}

Neonates at term birth have a total body store of about $270 \mathrm{mg}$ of iron, all derived from the mother. Some of this iron is made available from the stopping of menses, and some from increased absorption during pregnancy. The mother will however have to provide about $400 \mathrm{mg}$ from her own hepatic stores. Moreover, extra iron is required for the formation of the placenta, as well as to expand maternal red cell mass and cope with blood loss during delivery. ${ }^{141}$ Women often become pregnant without adequate iron reserves or are already iron deficient. The most severe consequence of iron depletion is maternal iron deficiency anemia (IDA). IDA may be aggravated during pregnancy owing to fetal demands for iron. ${ }^{142}$ Iron status seems to be implicated in some pregnancy disorders affecting mother and fetus, such as preeclampsia, prematurity and premature rupture of membranes. ${ }^{143,144}$ In a prospective study of 1650 pregnancies, low iron status early in pregnancy was found to be inversely related to placental size. ${ }^{145}$ Either anemia in the periconceptional period may have an independent effect on infant growth by influencing hormone synthesis, ${ }^{146}$ or the moderate preconceptional anemia may turn to a more severe anemia during pregnancy ${ }^{142}$ leading to the observed growth deficits. Animal studies suggest that maternal IDA may be a predictor for increased disease risk in later life, ${ }^{147}$ and recently it has been hypothesized that maternal iron status might be involved in cognitive development of the infant. ${ }^{148}$ Some studies showed that maternal IDA is linked to altered infant behavioral and neural development, and suggested to result in irreversible effects on neurochemistry and neurobiology due to altered myelination of white matter, changes in monoamine metabolism in striatum and functioning of the hippocampus. ${ }^{149-151}$

\subsubsection{Iron supplementation}

An adequate iron intake is mandatory for normal fetal growth and development. Nevertheless, an unresolved question is whether prophylactic iron supplementation does reduce the rates of pregnancy complications, ${ }^{152}$ or whether anemia affects placental development solely during early pregnancy and therefore would prevent complications by supplementation prior to pregnancy. Routine iron supplementation is still common during pregnancy but potentially harmful effects in iron sufficient women are debated. In general, randomized controlled trials showed that prophylactic iron supplementation during early pregnancy (i.e., $30-40 \mathrm{mg} /$ day taken from the 20th week of gestation until delivery) can increase hemoglobin concentrations and body iron stores in pregnant women. ${ }^{153-156}$ Nevertheless, results related to clinical endpoints are conflicting. Some authors reported that supplementation increased birthweight and reduced the incidence of preterm delivery, ${ }^{152,157}$ whereas others found no effect ${ }^{155,158}$ or negative effects on clinical endpoints, possibly due to untoward effects of iron overload in non-anemic mothers. ${ }^{133}$ In this context, Ziaei and colleagues ${ }^{149}$ concluded that routine iron 
supplementation $(50 \mathrm{mg})$ in non-anemic women was not rational and might be harmful. Their randomized controlled trial evidenced that small-for-gestational-age (SGA) birth rate and the number of women with hypertension disorders increased significantly in the intervention in comparison with the control group, being $15.7 \%$ vs $10.3 \%, p=0.035$, and $2.7 \%$ vs $8 \%, p=0.05$, respectively. The dosage of iron is a critical issue in relation to potential side effects. In excess, iron may be toxic because of its ability to generate reactive oxygen species and to induce cell and tissue damage. ${ }^{159}$ During pregnancy, increased numbers of mitochondria lead to increased synthesis of unpaired electrons and therefore may contribute to oxidative stress, with a peak vulnerability during the second half of pregnancy for fetal health and gestational outcomes. ${ }^{160}$ A recent observation study reported a 2-fold higher prevalence of GDM, hypertension, and metabolic syndrome in mid-pregnancy among iron-supplement users, ${ }^{161}$ suggesting that iron excess should be avoided. 160

However, iron deficiency anemia should certainly be prevented and treated. Selective prophylaxis seems to be the most effective and appropriate approach: screening of ferritin levels in early pregnancy may identify women who may benefit from iron supplementation.

Ongoing studies are evaluating the effect of different timing of iron supply in pregnancy (i.e. early or late pregnancy) as well as the different frequency of supplementation (i.e., daily or weekly). Moreover, different forms of iron supplements are of interest given that iron status is influenced both by the iron content and the bioavailability of iron: indeed heme iron from animal foods is better absorbed than non-heme iron from vegetables. Similarly FeEDTA and liposome embedded/encapsulated forms may have a higher bioavailability than ferrous fumarate or FeSO $4 .{ }^{162-164}$ Polymeric forms may have advantages because of a lesser likelihood to be reactive. The further exploration of different strategies could inform future practice recommendations.

\subsection{Iodine}

Approximately half of the European population is still suffering from an inadequate iodine supply. Low urinary iodine excretion is especially common among pregnant women and school children.

Table 3

Micronutrient dietary sources, dietary reference intakes for pregnant women, unresolved issues and proposal of priority for future research in pregnancy.

\begin{tabular}{|c|c|c|c|c|}
\hline \multirow[t]{2}{*}{ Micronutrient } & \multirow[t]{2}{*}{ Dietary source } & \multirow{2}{*}{$\begin{array}{l}\text { Dietary Reference } \\
\text { Intakes (DRIs) }\end{array}$} & \multicolumn{2}{|l|}{ Issues } \\
\hline & & & To be re-assessed & Priority for future research \\
\hline $\begin{array}{l}\text { Folate (DEF) } \\
\quad(\mu \mathrm{g} / \text { day })\end{array}$ & $\begin{array}{l}\text { Enriched cereal grains, dark leafy } \\
\text { vegetables, enriched and whole-grain } \\
\text { breads and bread products, fortified } \\
\text { ready-to-eat cereals }\end{array}$ & $\begin{array}{l}600 \text { (FAO/ } \\
\text { WHO })^{11} ; \\
600(\mathrm{IOM})^{84} ; \\
300 \\
(\mathrm{COMA}, \mathrm{UK})^{85} ; \\
600(\mathrm{D}-\mathrm{A}-\mathrm{CH})^{86} ; \\
600 \\
\text { (Australia) }^{103} \\
500 \text { (NNR }^{177}\end{array}$ & $\begin{array}{l}400^{\mathrm{a}} \text { from } 4 \text { wks before until } \\
12 \text { wks after conception }{ }^{21}\end{array}$ & $\begin{array}{l}\text { Dose/timing combination: } 400 \text { starting } \\
8-12 \text { wks before pregnancy or } 800 \\
\text { starting } 4 \text { wks before pregnancy. } \\
\text { Investigation on toxicity of chronic } \\
\text { high doses }\end{array}$ \\
\hline $\begin{array}{l}\text { Vitamin A (retinol } \\
\text { equivalent) } \\
\text { (mg/day) }\end{array}$ & $\begin{array}{l}\text { Liver, dairy products, fish, darkly } \\
\text { colored fruits, leafy vegetables }\end{array}$ & 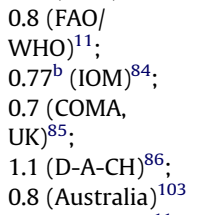 & $\begin{array}{l}\text { To avoid intake } \\
\text { of vitamin A rich liver } \\
\text { and liver foods during } \\
\text { pregnancy }\end{array}$ & $\begin{array}{l}\text { To investigate effects of higher intakes } \\
\text { of vitamin A during the 3rd trimester } \\
\text { of gestation }\end{array}$ \\
\hline $\begin{array}{l}\text { Vitamin D } \\
\quad(\mu \mathrm{g} / \text { day })\end{array}$ & $\begin{array}{l}\text { Fish liver oils, flesh of fatty fish, liver, } \\
\text { eggs, fortified milk products, fortified } \\
\text { cereals }\end{array}$ & $\begin{array}{l}5 \text { (FAO/WHO }^{11} \\
10(\mathrm{UK})^{104} \\
15(\mathrm{IOM})^{105} \\
5 \text { (D-A-CH }^{86} \\
5 \text { (Australia) }^{103}\end{array}$ & $\begin{array}{l}\text { Optimal dose of Vitamin D } \\
\text { to achieve sufficiency. }\end{array}$ & $\begin{array}{l}\text { To determine optimal 25[OH]D concentrations } \\
\text { with regards to bone health and non-classical } \\
\text { actions of vitamin D on maternal and fetal } \\
\text { outcomes. } \\
\text { Need of selecting high risk population for } \\
\text { routine supplementation during/before } \\
\text { pregnancy. }\end{array}$ \\
\hline Iron (mg/day) & $\begin{array}{l}\text { Fruits, vegetables, fortified bread and } \\
\text { grain products such as cereal (nonheme } \\
\text { iron), meat and poultry (heme iron) }\end{array}$ & $\begin{array}{l}27(\mathrm{IOM})^{84} \\
14.8 \\
\left(^{\mathrm{COMA}, \mathrm{UK}}\right)^{85} \\
30 \text { (D-A-CH }^{86} \\
27 \text { (Australia) }^{103}\end{array}$ & Routine iron supplementation & $\begin{array}{l}\text { Selective prophylactic supplementation. } \\
\text { To avoid overload. } \\
\text { To evaluate the effects of timing and } \\
\text { frequency of supplementation, and to } \\
\text { investigate the bioavailability of different } \\
\text { forms of supplements }\end{array}$ \\
\hline Iodine ( $\mu \mathrm{g} /$ day) & $\begin{array}{l}\text { Marine origin, processed foods, } \\
\text { iodized salt }\end{array}$ & 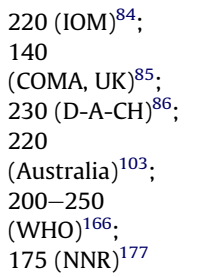 & $\begin{array}{l}\text { Supplementation of } 100 \\
-150 \mu \mathrm{g} \text { Iodine in countries } \\
\text { with a mean iodine uptake } \\
\text { below } 150 \mu \mathrm{g} / \text { day }\end{array}$ & $\begin{array}{l}\text { To control urinary iodine (UI) excretion by } \\
\text { epidemiological studies under the current } \\
\text { push to reduce salt intake in } \\
\text { the general population }\end{array}$ \\
\hline $\begin{array}{l}\text { ANTIOXIDANTS } \\
\text { Selenium } \\
\text { ( } \mu \mathrm{g} / \text { day) } \\
\text { (including } \\
\text { selenoproteins) }\end{array}$ & Bread and cereals, meat, milk/dairy ${ }^{178}$ & $\begin{array}{l}28 \text { (2nd } \\
\text { trimester) }-30 \\
(3 \text { rd trimester) } \\
(\text { FAO/WHO) })^{11} ; \\
60(\mathrm{IOM})^{84} ; \\
60 \text { (COMA, UK) }^{85} \text {; } \\
65{\text { (Australia })^{103} ;} \text {; } \text { (NNR) }^{177}\end{array}$ & $\begin{array}{l}\text { Circumstantial evidence that } \\
\text { selenium supplements may } \\
\text { prevent preeclampsia }\end{array}$ & $\begin{array}{l}\text { To investigate other more specifically } \\
\text { targeted antioxidant strategies for } \\
\text { prevention of preeclampsia including } \\
\text { an RCT of selenium supplementation in } \\
\text { low selenium populations }\end{array}$ \\
\hline
\end{tabular}

\footnotetext{
${ }^{\mathrm{a}} \mathrm{DEF}=$ Dietary Folate Equivalents.

b $\mathrm{RAE}=$ Retinol Activity Equivalent.
} 
During pregnancy the demand for iodine is substantially higher than in non-pregnant women increasing from at least $100 \mu \mathrm{g} / \mathrm{day}$ to about $200-250 \mu \mathrm{g} /$ day to maintain free thyroxine (fT4) during pregnancy within the normal range. This is because of the increased demand for thyroxine during the first trimester, the increase in thyroxine-binding protein and the higher loss of iodine in the urine. ${ }^{165}$ The WHO recommendation for iodine intake during pregnancy and lactation has recently increased from 200 to $250 \mu \mathrm{g} /$ day and suggested that a median urinary iodine concentration (UIC) of $150-250 \mu \mathrm{g} / \mathrm{L}$ indicates adequate iodine intake. ${ }^{166}$ WHO recommends iodine supplementation in pregnancy only in countries where less than $90 \%$ of households use iodized salt or where the median UIC in school children is below $100 \mu \mathrm{g} / \mathrm{L}$. However, the use of iodized salt in households might be not enough to cope with the increased iodine demand during pregnancy and therefore the American Thyroid Association recommends an iodine supplementation of $150 \mu \mathrm{g} /$ day in pregnant women. ${ }^{167}$

Low iodine intake in pregnancy is associated with a higher incidence of miscarriage, SGA infants, and a delay in mental development or even permanent mental retardation, reduced intellectual ability and hearing loss. ${ }^{166}$ Thyroxine is necessary for normal brain development ${ }^{168}$ and therefore a sufficient iodine intake especially within the first trimester is important. ${ }^{169}$ Even mild iodine deficiency and subclinical hypothyroidism may affect fetal growth. Pregnant women with UICs during the 3rd trimester below $50 \mu \mathrm{g} / \mathrm{L}$ were significantly more likely to have a SGA infant, and mean birthweight was lower, than among women with the UICs between 100 and $149 \mu \mathrm{g} / \mathrm{L}$ [adjusted odd ratio (95\%CI): 0.15 (0.03-0.76)]. Higher TSH levels were also associated with a higher risk of having an SGA baby or a LBW newborn. ${ }^{170}$ The later mean intelligence quotient of children born to women an UIC below $50 \mu \mathrm{g} / \mathrm{L}$ was found significantly lower compared to controls with adequate iodine supplementation. ${ }^{171}$ Recent cross-sectional studies in European countries and the USA show a median UIC in pregnant women in the range of $95-130 \mu \mathrm{g} / \mathrm{L}^{166,172}$

Excessive iodine intake like in Japan did not affect either the maternal or the off-spring thyroid function. ${ }^{173}$ Other studies show an increase in iodine-induced hyperthyroidism in areas with previously low iodine intake and also a higher prevalence of autoimmune thyroiditis (AIT) is discussed. ${ }^{166}$ Therefore, it has been suggested to test the thyroid function of women who plan a pregnancy in geographical areas with known iodine deficiency, but this concept is controversial. ${ }^{174}$

During the 1 st trimester the fetus depends on the thyroxine supplied by the mother, and thereafter mainly on maternal iodine intake. The maternal fT4 concentration therefore is more important for fetal brain development than TSH, although elevated TSH may indicate a deficient thyroid reserve of the mother and AIT should then be excluded. ${ }^{168,172}$ If AIT is confirmed, L-Thyroxin supplementation is indicated to keep TSH and fT4 within the low normal range. After the 12 th week of gestation, iodine should be added in a dosage of $150 \mu \mathrm{g} / \mathrm{day}$. If AIT is excluded, only iodide supplementation $(150-200 \mu \mathrm{g} /$ day) is recommended throughout pregnancy and lactation in several countries with frequent occurrence of iodine deficiency (e.g. Germany), but obviously the iodine dose supplied to prevent and treat iodine-deficiency disorders should be at a safe level. If iodine status is good (median UIC, 200-299 $\mu \mathrm{g} / \mathrm{L}$ ) or excessive (median UIC, $>300 \mu \mathrm{g} / \mathrm{L}$ ) additional supplementation should be avoided. Iodized salt should be provided only in regions where iodine intake is insufficient according to the WHO recommendations.

The thyroid is the organ with the body's highest selenium content. Combined iodine and selenium deficiency is the cause of myxoedematous cretinism. This is because selenium-dependent enzymes (GPx's) are important to prevent the thyroid from oxidative damage. ${ }^{175}$ Sufficient dietary iodine and selenium intakes are necessary for normal thyroid function and low selenium intake might initiate or exacerbate AIT. Selenium supplementation in countries with low selenium intake might attenuate the inflammatory activity within the thyroid in patients suffering from AIT. Supplementation of $200 \mu$ g selenium per day during pregnancy and 9 months after delivery in women suffering from AIT was reported to prevent the post-partum exacerbation of AIT and decreasing the incidence of post-partum hypothyroidism. ${ }^{176}$ This study, however, needs confirmation especially in countries with sufficient selenium intake.

\section{Conclusions}

In addition to their classical essential roles, current evidence seems to suggest that vitamins and minerals have added biofunctionality which may be particularly important in pregnancy. In particular, besides meeting desirable intakes, the balance between antioxidants and pro-oxidants needs to be sustained. For example supplementation with iron should not be excessive in order to avoid adverse outcomes. Moreover, synergisms between different micronutrients may enhance their biological potential, for example, the combination of folic acid and vitamin $B_{12}$ appears to further reduce the risk of occurrence of NTDs.

In this context, more information on the biological mechanisms underpinning relationships between micronutrients and pregnancy outcomes is needed Moreover, discrepancy between results from observational studies and randomized controlled studies often exists (i.e., role of folic acid in carcinogenesis), and data from trials are often conflicting as well, as suggested for example by the disagreement on the need for iron prophylaxis or on the harmful amount and timing of vitamin A intake (Table 3). Similarly, large trials evidenced no effect of the prophylactic use of high doses of vitamin $C$ and vitamin $E$ combined on the prevention of preeclampsia. Moreover, it should be investigated whether the strategy of increasing folic acid dose from 400 to $800 \mu \mathrm{g} /$ day may be applicable to pregnancy state where adaptation happens to increase absorption of nutrients. Vitamin D insufficiency is increasingly common amongst pregnant women and the consequences may extend beyond the recognized influence of neonatal calcium deficiency and rickets. The proposed relationships between hypovitaminosis and gestational diabetes, and with preeclampsia, require further investigation, as does the influence of maternal supplements required to achieve sufficiency. Adequately powered, randomized controlled trials with long periods of follow-up are needed to establish causality and the best formulation, dose, duration and period of supplementation during pregnancy. The influence on the health of the child in later life should routinely be considered. Clearly, further studies are needed to determine the optimal 25[OH]D concentrations with regards not only to bone health but also to non-classic actions of vitamin D on maternal and fetal outcomes. The benefit of iodine for the brain development of the offspring during pregnancy is well established. The main source of iodine is the use of iodized salt in household and food industry. The current recommendations to reduce salt intake to prevent hypertension might influence iodine uptake of women in childbearing age and therefore especially also in developed countries surveys of iodine intake is recommended and increase of the amount of iodine in fortified salt has to be considered.

Micronutrient deficiencies can undoubtedly have profound influences on the health of the mother and her child, but they remain areas of uncertainty and controversy which hinder the development of robust public health guidance, Many of these, addressed in the review, would be clarified by well conducted randomized controlled clinical trials including childhood follow- 
up. These are an essential pre-requisite to inform evidence based policy decisions and recommendations for clinical practice.

\section{Conflict of interest}

The authors do not report a potential conflict of interest.

\section{Statement of authorship}

We hereby certify that it is an original publication, the manuscript has not been previously submitted or published elsewhere. CB prepared the first draft of the manuscript, and HB, RG, AL, KP, LP, $\mathrm{CR}$, BK and IC contributed to writing the final version of manuscript. All authors have made substantial contributions to and approved the final version of the manuscript.

\section{Acknowledgments}

The workshop on which this manuscript is based was funded by the charitable Child Health Foundation, Munich, Germany (Stiftung Kindergesundheit, www.kindergesundheit.de). The work report herein has been carried out within the EURRECA Network of Excellence (www.eurreca.org) which is financially supported by the Commission of the European Communities, specific Research Technology and Development (RTD) Programme Quality of Life and Management of Living Resources, within the Sixth Framework Programme, contract no. 036196. This report does not necessarily reflect the Commission's views or its future policy in this area. BK is the recipient of a Freedom to discover Award of the Bristol Myers Squibb Foundation, New York, NY, USA.

\section{References}

1. Biesalski HK. The significance of vitamin A for the development and function of the lung. Forum Nutr 2003;56:37-40.

2. Doyle W, Srivastava A, Crawford MA, Bhatti R, Brooke Z, Costeloe KL. Interpregnancy folate and iron status of women in an inner-city population. Brit Nutr 2001;86:81-7.

3. Shohaimi S, Bingham S, Welch A, Luben R, Day N, Wareham N, et al. Occupational social class, educational level and area deprivation independently predict plasma ascorbic acid concentration: a cross-sectional population based study in the Norfolk cohort of the European Prospective Investigation into Cancer (EPIC-Norfolk). Eur J Clin Nutr 2004;58:1432-5.

4. Bates CJ, Prentice A, Cole TJ, van der Pols JC, Doyle W, Finch S, et al. Micronutrients: highlights and research challenges from the 1994-5 National Die and Nutrition Survey of people aged 65 years and over. Brit J Nutr 1999;82:7-15.

5. Darmon N, Drewnowski A. Does social class predict diet quality? Am J Clin Nutr 2008;87:1107-17.

6. Cetin I, Berti C, Calabrese S. Role of micronutrients in the periconceptional period. Hum Reprod Update 2010;16:80-95

7. Berti C, Decsi T, Dykes F, Hermoso M, Koletzko B, Massari M, et al. Critical issues in setting micronutrient recommendations for pregnant women: an insight. Matern Child Nutr 2010;6:5S-22S.

8. Thomas M, Weisman SM. Calcium supplementation during pregnancy and lactation: effects on the mother and the fetus. Am J Obstet Gyneco 2006;194:937-45.

9. Pitkin RM. Folate and neural tube defects. Am J Clin Nutr 2007;85:285S-8S.

10. McArdle HJ, Ashworth CJ. Micronutrients in fetal growth and development. $B r$ Med Bull 1999:55:499-510.

11. FAO/WHO Report. Vitamin and mineral requirements in human nutrition. 2nd ed. World Health Organization and Food and Agriculture Organization of the United Nations; 2004.

12. Pietrzik K, Golly I, Loew D. Handbuch Vitamine. Elsevier Urban \& Fischer; 2008.

13. Greene ND, Stanier P, Copp AJ. Genetics of human neural tube defects. Hum Mol Genet 2009;18:R113-29.

14. Locksmith GJ, Duff P. Preventing neural tube defects: the importance of periconceptional folic acid supplements. Obstet Gynecol 1998;91:1027-34.

15. Guéant JL, Guéant-Rodriguez RM, Anello G, Bosco P, Brunaud L, Romano C et al. Genetic determinants of folate and vitamin B12 metabolism: a common pathway in neural tube defect and down syndrome? Clin Chem Lab Med 2003;41:1473-7.

16. Obeid R, Herrmann W. Homocysteine, folic acid and vitamin B12 in relation to pre- and postnatal health aspects. Clin Chem Lab Med 2005;43:1052-7.

17. Sadananda Adiga MN, Chandy S, Ramaswamy G, Appaji L, Aruna Kumari BS, Krishnamoorthy L. Association between plasma homocysteine and riboflavin status in acute lymphoblastic leukemia in children. Indian J Clin Biochem 2009;24:257-61.

18. Dhillon V, Thomas P, Fenech M. Effect of common polymorphisms in folate uptake and metabolism genes on frequency of micronucleated lymphocytes in a South Australian cohort. Mutat Res 2009;665:1-6.

19. de Bree A, Verschuren WM, Bjørke-Monsen AL, van het Hof KH, Steegersheunissen RPM. Effect of the methylenetetrahydrofolate reductase $677 \mathrm{C} \rightarrow \mathrm{T}$ mutation on the relations among folate intake and plasma folate and homocysteine concentrations in a general population sample. Am J Clin Nutr 2003;77:687-93.

20. Blom HJ. Folic acid, methylation and neural tube closure in humans. Birth Def Res (Part A) 2009;85:295-302.

21. MRC Vitamin Study Research Group. Prevention of neural tube defects: results of the Medical research Council vitamin study. Lancet 1991;338:131-7.

22. Czeizel AE, Dudás I. Prevention of the first occurrence of neural-tube defects by periconceptional vitamin supplementation. N Engl J Med 1992;327:1832-5.

23. Czeizel AE, Dudás I, Métneki J. Pregnancy outcomes in a randomised controlled trial of periconceptional multivitamin supplementation. Final report. Arch Gynecol Obstet 1994;255:131-9.

24. Czeizel AE, Dobó M, Vargha P. Hungarian cohort-controlled trial of periconceptional multivitamin supplementation shows a reduction in certain congenital abnormalities. Birth Def Res (Part A) 2004:70:853-61.

25. Daly LE, Kirke PN, Molloy A, Weir DG, Scott JM. Folate levels and neural tube defects. Implication for prevention. JAMA 1995;274:1698-702.

26. Thamm M. Folsäureversorgung von Frauen im gebärfähigen Alter. Berliner Ärzte 2001;8:21-4.

27. Pietrzik K, Prinz-Langenohl R, Lamers $Y$, Wintergerst ES, Brämswig S Randomized, placebo-controlled, double-blind study evaluating the effectiveness of a folic acid containing multivitamin supplement in increasing erythrocyte folate levels in young women of child-bearing age. Ann Nutr Metab; 2005. 6.7.29 S.368.

28. Lamers Y, Prinz-Langenohl R, Brämswig S, Pietrzik K. Red blood cell folate concentrations increase more after supplementation with [6S]-5methyltetrahydrofolate than with folic acid in women of childbearing age. Am J Clin Nutr 2006;84:156-61.

29. Shaw GM, Carmichael SL, Nelson V, Selvin S, Schaffer DM. Occurrence of low birthweight and preterm delivery among California infants before and after compulsory food fortification with folic acid. Public Health Rep 2004;119: 170-3.

30. Nelen WL, Blom HJ, Steegers EA, den Heijer M, Thomas CM, Eskes TK. Homocysteine and folate levels as risk factors for recurrent early pregnancy loss. Obstet Gynecol 2000;95:519-24.

31. Vollset SE, Refsum H, Irgens LM, Emblem BM, Tverdal A, Gjessing HK, et al Plasma total homocysteine, pregnancy complications, and adverse pregnancy outcomes: the Hordaland homocysteine Study. Am J Clin Nutr 2000;71:962-8.

32. El-Khairy L, Vollset SE, Refsum H, Ueland PM. Plasma total cysteine, pregnancy complications, and adverse pregnancy outcomes: the Hordaland homocysteine study. Am J Clin Nutr 2003;77:467-72.

33. Steegers-Theunissen RP, Van Iersel CA, Peer PG, Nelen WL, Steegers EA. Hyperhomocysteinemia, pregnancy complications, and the timing of investigation. Obstet Gynecol 2004;104:336-43.

34. Mills JL, McPartlin JM, Kirke PN, Lee JL, Conley MR, Weir DG. Homocysteine metabolism in pregnancies complicated by neural-tube defects. Lancet 1995;345:149-51.

35. Homocysteine Lowering Trialists' Collaboration. Lowering blood homocysteine with folic acid based supplements: meta-analysis of randomised trials. BMJ 1998;316:894-8.

36. Clarke R, Refsum H, Birks J, Evans JG, Johnston C, Sherliker P, et al. Screening for vitamin B12 and folate deficiency in older persons. Am J Clin Nutr 2003;77:1241-7.

37. Van der Put NMJ, Eskes TKAB, Blom HJ. Is the common $677 \mathrm{C} \rightarrow \mathrm{T}$ mutation in the methylenetetrahydrofolate reductase gene a risk factor for neural tube defects? A meta-analysis. OJMed 1997;90:111-5.

38. Van der Molen EF, Arends GE, Nelen WL, van der Put NJ, Heil SG, Eskes TK, et al. A common mutation in the 5,10-MTHFR gene as a new risk factor for placental vasculopathy. Am J Obstet Gynecol 2000;182:1258-63.

39. Nurk E, Tell GS, Refsum H, Ueland PM, Vollset SE. Associations between maternal MTHFR polymorphisms and adverse outcomes of pregnancy: the Hordoland homocysteine study. Am J Med 2004;117:26-31

40. Mtiraoui N, Zammiti W, Ghazouani L, Braham NJ, Saidi S, Finan RR, et al. MTHFR C677T and A1298C polymorphism and changes in homocysteine concentrations in women with idiopathic recurrent pregnancy losses. Reproduction 2006;131:395-401.

41. McNulty $\mathrm{H}$, Scott JM. Intake and status of folate and related B-vitamins: considerations and challenges in achieving optimal status. $\mathrm{Br} \mathrm{J} \mathrm{Nutr}$ 2008;99:S48-54.

42. Institute of Medicine. Panel on Folate, Other B Vitamins, and Choline. Dietary Reference Intake; Thiamine, Riboflavin, Niacin, Vitamin B6, Folate, Vitamin B12, Pantothenic Acid, Biotin, and Choline. Washington, DC: National Academy Press; 1998.

43. Cuskelly GJ, Mooney KM, Young IS. Folate and vitamin B12: friendly or enemy nutrients for the elderly. Proc Nutr Soc 2007;66:548-58.

44. Morris MS, Jacques PF, Rosenberg IH, Selhub J. Circulating unmetabolized folic acid and 5-methyltetrahydrofolate in relation to anemia, macrocytosis, and cognitive test performance in American seniors. Am JClin Nutr 2010;91:1733-44. 
45. Ulrich CM, Potter JD. Folate supplementation: too much of a good thing? Cancer Epidemiol Biomarkers Prev 2006;15:189-93.

46. Simmer K, James C, Thompson RPH. Are iron-folate supplements harmful? Am J Clin Nutr 1987;5:122-5.

47. Green TJ, Skeaff M, Whiting SJ, Gibson RS. Effect of folic acid supplementation on plasma zinc concentrations of young women. Nutr 2003;19:522-3.

48. Valko M, Leibfritz D, Moncol J, Cronin MTD, Mazura M, Telser J. Free radicals and antioxidants in normal physiological functions and human disease. Int J Biochem Cell Biol 2007;39:44-84.

49. Taylor CT. Antioxidants and reactive oxygen species in human fertility. Envir Toxicol Pharmacol 2001;10:189-98.

50. Agarwal A Gupta S, Sharma RK. Role of oxidative stress in female reproduction. Reprod Biol Endocrinol 2005;3:28. doi:10.1186/1477-7827-3-28. published online.

51. Agarwal A, Gupta S, Sekhon L, Shah R. Redox considerations in female reproductive function and assisted reproduction: from molecular mechanisms to health implications. Antioxid Redox Signal 2008;10:1375-403.

52. Ruder EH, Hartman TJ, Blumberg J, Goldman MB. Oxidative stress and antioxidants: exposure and impact on female fertility. Hum Reprod Update 2008; 14:345-57.

53. Grimble RF. Nutritional modulation of cytokine biology. Nutr 1998;14:634-40.

54. Redman CW, Sacks GP, Sargent IL. Preeclampsia: an excessive maternal inflammatory response to pregnancy. Am J Obstet Gynecol 1999;180:499-506.

55. Raijmakers MT, Dechend R, Poston L. Oxidative stress and pre-eclampsia; rationale for antioxidant clinical trials. Hypertension 2004:44:374-80.

56. Moffet A, Loke C. Immunology of placentation in eutherian mammals. Nat Rev 2006:6:584-94.

57. Burton GJ, Hung T-H. Hypoxia-reoxygenation; a potential source of placental oxidative stress in normal pregnancy and preeclampsia. Fet Mat Med Rev 2003;14(2):97-117.

58. Fernández-Riejos P, Najib S, Santos-Alvarez J, Martín-Romero C, PérezPérez A, González-Yanes C, et al. Role of leptin in the activation of immune cells. Mediators Inflamm 2010;2010(568343).

59. Perkins AV. Endogenous anti-oxidants in pregnancy and preeclampsia. Aust New Zealand J Obstetr Gynaecol 2006;46:77-83.

60. Rasmussen KM, Kjolhede CL. Maternal obesity: a problem for both mother and child. Obesity 2008;16:929-31.

61. Hauguel-de Mouzon S, Lepercq J, Catalano P. The known and unknown of leptin in pregnancy. Am J Obstet Gynecol 2006;194:1537-45.

62. Ahima RS, Flier RJ. Adipose tissue as an endocrine organ. TEM 2000:11:327-32.

63. Sullivan DR, Celermajer DS, Le Couteur DG, Lam CVk. The vascular implications of post-prandial lipoprotein metabolism. Clin Biochem Rev 2004;25:19-30.

64. Van Oostrom AJHHM, Sijmonsma TP, Verseyden C, et al. Postprandial recruitment of neutrophils may contribute to endothelial dysfunction. J Lipid Res 2003;44:576-83.

65. Hofmeyr GJ, Lawrie TA, Atallah AN, Duley L. Calcium supplementation during pregnancy for preventing hypertensive disorders and related problems. Cochrane Database Syst Rev 2010;8. CD001059.

66. Teegarden D, Gunther CW. Can the controversial relationship between dietary calcium and body weight be mechanistically explained by alterations in appetite and food intake? Nutr Rev 2008;66:601-5.

67. Fritsche K. Fatty acids as modulators of the immune response. Annu Rev Nutr 2006;26:45-73.

68. Horvath A, Koletzko B, Szajewska H. Effect of supplementation of women in high-risk pregnancies with long-chain polyunsaturated fatty acids on pregnancy outcomes and growth measures at birth: a meta-analysis of randomized controlled trials. Br J Nutr 2007;98:253-9.

69. Olafsdottir AS, Skuladottir GV, Thorsdottir I, Hauksson A, Thorgeirsdottir $\mathrm{H}$ Steingrimsdottir L. Relationship between high consumption of marine fatty acids in early pregnancy and hypertensive disorders in pregnancy. BJOG 2006;113:301-9.

70. Chappell LC, Seed PT, Briley AL, Kelly FJ, Lee R, Hunt BJ, et al. Effect of antioxidants on the occurrence of pre-eclampsia in women at increased risk: a randomised trial. Lancet 1999;354:810-6.

71. Polyzos NP, Mauri D, Tsappi M, Tzioras S, Kamposioras K, Cortinovis I, et al. Combined vitamin $\mathrm{C}$ and $\mathrm{E}$ supplementation during pregnancy for preeclampsia prevention: a systematic review. Obstet Gynecol Surv 2007;62:202-6.

72. Poston L, Briley AH, Seed PT, Kelly FJ, Shennan AH, for the Vitamins in Preeclampsia (VIP) consortium. Vitamin $\mathrm{C}$ and vitamin $\mathrm{E}$ in pregnant women at risk for pre-eclampsia (VIP trial): randomised placebo-controlled trial. Lancet 2006;367:1145-54.

73. Reiter E, Jiang Q Stephan Christen S. Anti-inflammatory properties of $\alpha$ - and $\gamma$-tocopherol. Mol Aspects Med 2007;28:668-91.

74. Rumbold AR, Crowther CA, Haslam RR, Dekker GA, Robinson JS, for the ACTS study group. Vitamins $\mathrm{C}$ and $\mathrm{E}$ and the risks of pre-eclampsia and perinatal complications. NEJM 2006;354:1796-806.

75. Villar J, Purwar M, Merialdi M, Zavaleta N, Thi Nhu Ngoc N, Anthony J, et al, on behalf of the WHO Vitamin C and Vitamin E trial group. World Health Organisation multicentre randomised trial of supplementation with vitamins $\mathrm{C}$ and $\mathrm{E}$ among pregnant women at high risk for pre-eclampsia in populations of low nutritional status from developing countries. BJOG 2009;116:780-8.
76. Roberts JM, Myatt L, Spong CY, Thom EA, Hauth JC, Leveno KJ, et al, for the Eunice Kennedy Shriver National Institute of Child Health and Human Development Maternal-Fetal Medicine Units Network. Vitamins C and E to prevent complications of pregnancy-associated hypertension. $N$ Engl J Med 2010;362:1282-91.

77. Afzhal-Ahmed I, Mann CE, Shennan AH, Poston L, Naftalin RJ. Pre-eclampsia inactivates glucose-6-phopshate dehydrogenase and impairs the redox status of erythrocytes and fetal endothelial cells. Free Radic Biol Med 2007:42:1781-90.

78. Rayman MP, Bode P, Redman CWG. Low selenium status is associated with the occurrence of the pregnancy disease preeclampsia in women from the United Kingdom. Am J Obstet Gynecol 2003;189:1343-9.

79. Vanderlelie J, Venardos K, Clifton VL, Gude NM, Clarke FM, Perkins AV. Increased biological oxidation and reduced anti-oxidant enzyme activity in pre-eclamptic placentae. Placenta 2005;26:53-8.

80. Mistry HD, Wilson V, Ramsay MM, Symonds ME, Pipkin FB. Reduced Selenium concentrations and glutathione peroxidase activity in preeclamptic pregnancies. Hypertension 2008;52:881-8.

81. Vanderlelie J, Venardos K, Perkins AV. Selenium deficiency as a model of experimental pre-eclampsia in rats. Reproduction 2004;128:635-41.

82. Ross AC. Vitamin A and carotenoids. In: Shils ME, Shike M, Ross AC, editors. Modern mutrition in health and disease. 10th ed. USA: Lippincott Williams \& Wilkins; 2006. p. 351-75.

83. Grune T, Lietz G, Palou A, Ross AC, Stahl W, Tang G, et al. $\beta$-Carotene is an important vitamin A source for humans. J Nutr 2010;140:2268S-85S.

84. Institute of Medicine (IOM), Food and Nutrition Board. Dietary Reference Intakes for Vitamin A, Vitamin K, Arsenic, Boron, Chromium, Copper, Iodine, Iron, Manganese, Molybdenum, Nickel, Silicon, Vanadium, and Zinc. Washington, DC: National Academy Press. available at: http://www.nap.edu; 2001.

85. Panel on DRVs of the Committee on Medical Aspects of Food Policy (COMA). Dietary reference values (DRVs) for food energy and nutrients for the UK. Rep Health Soc Subjects 1991;41.

86. D-A-CH German Nutrition Society, Austrian Nutrition Society, Swiss Society for Nutrition Research. Reference Values for Nutrient Intake (D-A-CH); 2000. Frankfurt am Main.

87. Shenai JP, Chytil F, Stahlman MT. Liver vitamin A reserve of very low birth weight neonates. Pediatr Res 1985;19:892-3.

88. Shah RS, Rajalakshmi R, Bhatt RV, Hazra MN, Patel BC, Swamy NB, et al. Liver stores of vitamin $A$ in human fetuses in relation to gestational age, fetal size and maternal nutritional status. Br J Nutr 1987;58:181-9.

89. Gazala E, Sarov B, Hershkovitz E, Edvardson S, Sklan D, Katz M, et al. Retinol concentration in maternal and cord serum: its relation to birth weight in healthy mother-infant pairs. Early Hum Develop 2003;71:19-28.

90. Strobel M, Tinz J, Biesalski HK. The importance of beta-carotene as a source of vitamin A with special regard to pregnant and breastfeeding women. Eur J Nutr 2007;46:I/1-20.

91. American Academy of Pediatrics Committee on Nutrition. Nutritional needs of preterm infants. In: Kleinman RE, editor. Pediatric Nutrition Handbook. 4th ed. Elk Grove Village, IL: American Academy of Pediatrics; 1998. p. 55-87.

92. Schulz C, Engel U, Kreienberg L, Biesalski HK. Vitamin A and beta-carotene supply of women with Gemini or short birth intervals. A pilot study. Eur J Nutr 2007:46:12-20.

93. Bundesinstitut für Risikobewertung (BfR). Verwendung von Vitaminen in Lebensmitteln; 2004. Berlin.

94. Biesalski HK. Comparative assessment of the toxicology of vitamin A and retinoids in man. Toxicology 1989;57:117-61.

95. Leung WC, Hessel S, Méplan C, Flint J, Oberhauser V, Tourniaire F, et al. Two common single nucleotide polymorphisms in the gene encoding betacarotene 15,15 '-monoxygenase alter beta-carotene metabolism in female volunteers. FASEB J 2009;23:1041-53.

96. Azais-Bresco V, Pascal G. Vitamin A in pregnancy: requirements and safety limits. Am J Clin Nutr 2000;71:1325-33.

97. Almeras L, Eyles D, Benech P, Laffite D, Villard C, Patatian A, et al. Developmental vitamin $\mathrm{D}$ deficiency alters brain protein expression in the adult rat: implications for neuropsychiatric disorders. Proteomics 2007;7:769-80.

98. Bikle D. Nonclassic actions of vitamin D. I Clin Endocrinol Metab 2009;94:26-34

99. Hewison M. Vitamin D and innate immunity. Curr Opin Investig Drugs 2008;9:485-90.

100. Hollis BW. Circulating 25-hydroxyvitamin D levels indicative of vitamin D sufficiency: implications for establishing a new effective dietary intake recommendation for vitamin D. J Nutr 2005;135:317-22.

101. Hollis BW, Wagner CL. Normal serum vitamin D levels. $N$ Engl J Med 2005;352:515-6.

102. Standing Committee on the Scientific Evaluation of Dietary Reference Intakes, Food and Nutrition Board, Institute of Medicine. Dietary Reference Intakes for Calcium, Phosphorous, Magnesium, Vitamin D and Fluoride. Washington, DC: National Academies Press; 1997.

103. National Health and Medical Research Council of Australia. Vitamin D. National Health Medical Research Council. available at: http://www.nrv.gov. au/nutrients/vitamin\%2520d.htm; 2005.

104. United Kingdom Department of Health. Healthy Start: Vitamin Supplement Recommendations. London: United Kingdom Department of Health. available at: http://www.healthystart.nhs.uk/en/fe/vitamin_supplement_recommend ations.html; 2008.

105. IOM. Dietary Reference Intakes for Calcium and Vitamin D; Nov. 2010. 
106. Norman AW. From vitamin D to hormone D: fundamentals of the vitamin D endocrine system essential for good health. Am J Clin Nutr 2008:88:491S-9S.

107. Yetley EA, Brulé D, Cheney MC, Davis CD, Esslinger KA, Fischer PW, et al. Dietary reference intakes for vitamin D: justification for a review of the 1997 values. Am J Clin Nutr 2009;89:719-27.

108. Yetley EA. Assessing the vitamin D status of the US population. Am J Clin Nutr 2008;88:558S-64S.

109. Looker AC, Pfeiffer CM, Lacher DA, Schleicher RL, Picciano MF, Yetley EA Serum 25-hydroxyvitamin D status of the US population: 1988-1994 compared with 2000-2004. Am J Clin Nutr 2008;88:1519-27.

110. van der Meer IM, Karamali NS, Boeke AJ, Lips P, Middelkoop BJ, Verhoeven I, et al. High prevalence of vitamin $D$ deficiency in pregnant non-Western women in The Hague, Netherlands. Am J Clin Nutr 2006;84:350-3.

111. Bodnar LM, Simhan HN, Powers RW, Frank MP, Cooperstein E, Roberts JM High prevalence of vitamin D insufficiency in black and white pregnan women residing in the northern United States and their neonates. J Nutr 2007; 137:447-52.

112. Baker PN, Wheeler SJ, Sanders TA, Thomas JE, Hutchinson CJ, Clarke K, et al. A prospective study of micronutrient status in adolescent pregnancy. Am J Clin Nutr 2009;89:1114-24.

113. Shin JS, Choi MY, Longtine MS, Nelson DM. Vitamin D effects on pregnancy and the placenta. Placenta 2001;31:1027-34.

114. Kovacs CS. Vitamin D in pregnancy and lactation: maternal, fetal, and neonatal outcomes from human and animal studies. Am J Clin Nutr 2008;88:520S-8S.

115. Bodnar LM, Catov JM, Simhan HN, Holick MF, Powers RW, Roberts JM Maternal vitamin D deficiency increases the risk of preeclampsia. J Clin Endocrinol Metab 2007:92:3517-22.

116. Halhali A, Villa AR, Madrazo E, Soria MC, Mercado E, Díaz L, et al. Longitudina changes in maternal serum 1,25-dihydroxyvitamin $D$ and insulin like growth factor I levels in pregnant women who developed preeclampsia: comparison with normotensive pregnant women. J Steroid Biochem Mol Bio 2004;89-90:553-6.

117. Shaarawy M, Zaki S, Ramzi A-M, Salem ME, El-Minawi AM. Feto-maternal bone remodeling in normal pregnancy and preeclampsia. J Soc Gynecol Invest 2005; 12:343-8

118. Zhang C, Oiu C, Hu FB, David RM, van Dam RM, Bralley A, et al. Maternal plasma 25-hydroxyvitamin D concentrations and the risk for gestational diabetes mellitus. PLOS ONE 2008;3:e3753. doi:10.1371/journal.pone.0003753. published online.

119. Clifton-Bligh RJ, McElduff P, McElduff A. Maternal vitamin D deficiency, ethnicity and gestational diabetes. Diabet Med 2008:25:678-84

120. Maghbooli Z, Hossein-Nezhad A, Karimi F, Shafaei AR, Larijani B. Correlation between vitamin D3 deficiency and insulin resistance in pregnancy. Diabetes Metab Res Rev 2008;24:27-32.

121. Li YC. Vitamin D regulation of the renin-angiotensin system. J Cell Biochem 2003;88:327-31.

122. Cantorna MT, Zhu Y, Froicu M, Wittke A. Vitamin D status, 1,25-dihydroxyvitamin D3, and the immune system. Am J Clin Nutr 2004;80:1717S-20S.

123. Evans KN, Nguyen L, Chan J, Innes BA. Effects of 25-Hydroxyvitamin D3 and 1,25-dihydroxyvitamin D3 on cytokine production by human decidual cells. Biol Reprod 2006;75:816-22.

124. Saffery R, Ellis J, Morley R. A convergent model for placental dysfunction encompassing combined sub-optimal one-carbon donor and vitamin D bioavailability. Med Hypotheses 2009;73:1023-8.

125. Baker AM, Haeri S, Camargo Jr CA, Espinola JA, Stuebe AM. A nested casecontrol study of midgestation vitamin D deficiency and risk of severe preeclampsia. J Clin Endocrinol Metab 2010;95:5105-9.

126. Powe CE, Seely EW, Rana S, Bhan I, Ecker J, Karumanchi SA, et al. First trimester vitamin $\mathrm{D}$, vitamin $\mathrm{D}$ binding protein, and subsequent preeclampsia. Hypertension 2010;56:758.

127. Shand A, Nassar N, Von Dadelszen P, Innis SM, Green TJ. Maternal vitamin D status in pregnancy and adverse pregnancy outcomes in a group at high risk for pre-eclampsia. BJOG 2010;117:1593-8.

128. Peechakara SV, Pittas AG. Vitamin D as a potential modifier of diabetes risk. Nat Clin Pract Endocrinol Metab 2008;4:182-3.

129. Teegarden D, Donkin SS. Vitamin D: emerging new roles in insulin sensitivity. Nutr Res Rev 2009;22:82-92.

130. Chiu KC, Chu A, Go VL, Saad MF. Hypovitaminosis D is associated with insulin resistance and beta cell dysfunction. Am J Clin Nutr 2004;79:820-5.

131. Salle BL, Delvin EE, Lapillonne A, Bishop NJ, Glorieux FH. Perinatal metabolism of vitamin D. Am J Clin Nutr 2000;71:1317S-24S.

132. Krishnaveni GV, Veena SR, Winder NR, Hill JC, Noonan K, Boucher BJ, et al. Maternal vitamin D status during pregnancy and body composition and cardiovascular risk markers in Indian children: the Mysore Parthenon Study. Am J Clin Nutr 2011;93:628-35.

133. Feron F, Burne TH, Brown J, Smith E, McGrath JJ, Mackay-Sim A, et al Developmental Vitamin D3 deficiency alters the adult rat brain. Brain Res Bull 2005;65:141-8.

134. Kesby JP, Burne TH, McGrath JJ, Eyles DW. Developmental vitamin D deficiency alters MK 801-induced hyperlocomotion in the adult rat: an animal model of schizophrenia. Biol Psychiatry 2006;60:591-6.

135. Zipitis CS, Akobeng AK. Vitamin D supplementation in early childhood and risk of type 1 diabetes: a systematic review and meta-analysis. Arch Dis Child 2008;93:512-7.
136. Stene LC, Joner G. Use of cod liver oil during the first year of life is associated with lower risk of childhood-onset type 1 diabetes: a large, population-based, case-control study. Am J Clin Nutr 2003;78:1128-34.

137. Camargo Jr CA, Rifas-Shiman SL, Litonjua AA, Rich-Edwards JW, Weiss ST Gold DR, et al. Maternal intake of vitamin D during pregnancy and risk of recurrent wheeze in children at $3 \mathrm{y}$ of age. Am J Clin Nutr 2007;85 788-95.

138. Devereux G, Litonjua AA, Turner SW, Craig LC, McNeill G, Martindale S, et al. Maternal vitamin $D$ intake during pregnancy and early childhood wheezing. Am J Clin Nutr 2007;85:853-9.

139. Lapillonne A. Vitamin D deficiency during pregnancy may impair maternal and fetal outcomes. Med Hypotheses 2010;74:71-5.

140. Roth DE. Vitamin D supplementation during pregnancy: safety considerations in the design and interpretation of clinical trials. J Perinatology; 2011. doi:10.1038/jp.2010.203.

141. Milman N. Iron and pregnancy-a delicate balance. Ann Hematol 2006;85:559-65.

142. Breymann C. Iron supplementation during pregnancy. Fet Mat Med Rev 2002;13:1-29.

143. Lao TT, Tham K-F, Chan LY. Third trimester iron status and pregnancy outcome in non-anemic women; pregnancy unfavourably affected by maternal iron excess. Hum Reprod 2000;15:1843-8.

144. Scholl TO. Iron status during pregnancy: setting the stage for mother and infant. Am J Clin Nutr 2005;81:1218S-22S

145. Hindmarsh PC, Geary MPP, Rodeck CH, Jackson MR, Kingdom JC. Effect of early maternal iron stores on placental weight and structure. Lancet 2000;356:719-23.

146. Allen LH. Biological mechanisms that might underlie iron's effects on fetal growth and preterm birth. J Nutr 2001;131:581S-9S

147. Gambling L, Dunford S, Wallace DI, Zuur G, Solanky N, Srai SK, et al. Iron deficiency during pregnancy affects postnatal blood pressure in the rat. J Physiol 2003;552(2):603-10.

148. Osendarp SJM, Murray-Kolb LE, Black MM. Case study on iron in mental development - in memory of John Beard (1947-2009). Nutr Rev 2010;68 S48-52.

149. Beard J. Iron deficiency alters brain development and functioning. J Nutr 2003;133:1468S-72S.

150. Beard JL. Why iron deficiency is important in infant development. $J$ Nutr 2008;138:2534-6.

151. Insel BJ, Schaefer CA, McKeague IW, Susser ES, Brown AS. Maternal iron deficiency and the risk of schizophrenia in offspring. Arch Gen Psychiatry 2008;65:1136-44

152. Siega-Riz AM, Hartzema AG, Turnbull C, Thorp J, McDonald T, Cogswell ME The effects of prophylactic iron given in prenatal supplements on iron status and birth outcomes: a randomized controlled trial. Am J Obstet Gynecol 2006;194:512-9.

153. Allen LH. Anemia and iron deficiency: effects on pregnancy outcome. Am J Clin Nutr 2000;71:1280S-4S

154. Makrides M, Crowther CA, Gibson RA, Gibson RS, Skeaff CM. Efficacy and tolerability of low-dose iron supplements during pregnancy: a randomized controlled trial. Am J Clin Nutr 2003;78:145-53.

155. Ziaei S, Mehrnia M, Faghihzadeh S. Iron status markers in nonanemic pregnant women with and without iron supplementation. Int Gynaecol Obste 2008;100:130-2.

156. Cogswell ME, Parvanta I, Ickes L, Yip R, Brittenham GM. Iron supplementation during pregnancy, anemia, and birth weight: a randomized controlled trial. Am J Clin Nutr 2003;78:773-81.

157. Milman N, Agger AO, Nielsen OJ. Iron status markers and serum erythropoietin in 120 mothers and newborn infants. Effect of iron supplementation in normal pregnancy. Acta Obstet Gyecol Scand 1994;73:200-4.

158. Ziaei S, Norrozi M, Faghihzadeh S, Jafarbegloo E. A randomised placebocontrolled trial to determine the effect of iron supplementation on pregnancy outcome in pregnant women with haemoglobin $\geq 13.2 \mathrm{~g} / \mathrm{dl}$. BJOC 2007; 114:684-8.

159. Paesano R, Pietropaoli M, Gessani S, Valenti P. The influence of lactoferrin, orally administered, on systemic iron homeostasis in pregnant women suffering of iron deficiency and iron deficiency anaemia. Biochimie 2009;91:44-51.

160. Casanueva E, Viteri FE. Iron and oxidative stress in pregnancy. J Nutr 2003;133:1700S-8S

161. Bo S, Menato G, Villois P, Gambino R, Cassader M, Cotrino I, et al. Iron supplementation and gestational diabetes in midpregnancy. Am J Obste Gynecol 2009;201:158.e1-6.

162. Hurrell RF, Reddy MB, Burri J, Cook JD. An evaluation of EDTA compounds for iron fortification of cereal-based foods. Br J Nutr 2000;84:903-10.

163. Mehansho H. Iron fortification technology development: new approaches. J Nutr 2006;136:1059-63.

164. Biebinger R, Zimmermann MB, Al-Hooti SN, Al-Hamed N, Al-Salem E, Zafar T, et al. Efficacy of wheat-based biscuits fortified with microcapsules containing ferrous sulfate and potassium iodate or a new hydrogen-reduced elemental iron: a randomised, double-blind, controlled trial in Kuwaiti women. Br J Nutr 2009;102:1362-9.

165. Glinoer D. The importance of iodine nutrition during pregnancy. Public Health Nutr 2007;10(12A):1542-6. 
166. Zimmermann MB. Iodine deficiency. Endocr Rev 2009;30:376-408.

167. Becker DV, Braverman LE, Delange F, Dunn JT, Franklyn JA, Hollowell JG, et al. Iodine supplementation for pregnancy and lactation - United States and Canada: recommendations of the American thyroid association. Thyroid 2006;16:949-51.

168. Morreale de Escobar G, Obregon MJ, Escobar del Rey F. Role of thyroid hormone during early brain development. Eur J Endocrinol 2004;151(Suppl. 3):U25-37.

169. Morreale de Escobar G, Obregón MJ, Escobar del Rey F. Iodine deficiency and brain development in the first half of pregnancy. Public Health Nutr 2007; 10:1554-70.

170. Alvarez-Pedrerol M, Guxens M, Mendez M, Canet Y, Martorell R, Espada M, et al. Iodine levels and thyroid hormones in healthy pregnant women and birth weight of their offspring. Eur J Endocrinol 2009;160:423-9.

171. Santiago-Fernandez P, Torres-Barahona R, Muela-Martínez JA, RojoMartínez G, García-Fuentes E, Garriga MJ, et al. Intelligence quotient and iodine intake: a cross-sectional study in children. J Clin Endocrinol Metab 2004;89:3851-7.
172. Gärtner R. Thyroid disease in pregnancy. Curr Opin Obstet Gynecol 2009;21:501-7.

173. Orito $\mathrm{Y}, \mathrm{Oku} \mathrm{H}$, Kubota $\mathrm{S}$, Amino $\mathrm{N}$, Shimogaki $\mathrm{K}$, Hata $\mathrm{M}$, et al. Thyroid function in early pregnancy in Japanese healthy women: relation to urinary iodine excretion, emesis, and fetal and child development. J Clin Endocrinol Metab 2009;94:1683-8.

174. Lazarus JH. Thyroid function in pregnancy. Br Bull Med; 2010.

175. Köhrle J, Gärtner R. Selenium and thyroid. Best Pract Res Clin Endocrinol Metab 2009;23:815-27.

176. Negro R, Greco G, Mangieri T, Pezzarossa A, Dazzi D, Hassan H. The influence of selenium supplementation on postpartum thyroid status in pregnant women with thyroid peroxidase autoantibodies. J Clin Endocrinol Metab 2007;92:1263-8.

177. Nordic Nutrition Recommendations (NNR). Integrating nutrition and physical activity. 4th ed. Copenhagen: Nordic Council of Ministers; 2004.

178. Fairweather-Tait SJ, Bao Y, Broadley MR, Collings R, Ford D, Hesketh JE, et al. Selenium in human health and disease. Antioxid Redox Signal 2011;14: 1337-83. 